بناء وتكاهل القدرات الدهاغية لدى العاديين وذوى صعوبات التعلم والموهوبين والمتفوقين

في إطار تطوير البنية العقلية هن أجل تمكين الإنسان الصري والموانية والعربي "رؤية سيكوفسيولوجية ونيوروسيكولوجية للمعالجة المعلوهاتية"(ورقة عمل)

إعداد

ه/ أهل مهيد غنايم هدرس التربية الخاصة قسم التربية الخاصة كلية التربية - جاهمة قناة السويس

\author{
د/ سليسمان عبدالواحد يوسف \\ دكتوراه صعوبات التعلم \\ كلية التزبية - جاهعة قناة السويس \\ استاذ صعوبات التعلم المساعد \\ كلية التربية - جاهعة جازان - السعودية ” سابقاً”
}

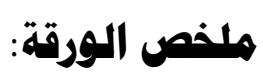

يُعد الدماغ الإنساني Human Brain أحد معجزات الخالق تبارك وتقدس، فهو من عجائب الدنيا، ومن أعظم مـا خُلق على وجـه الأرض وهو أرقى بكثير من سائر أدمغة فئة

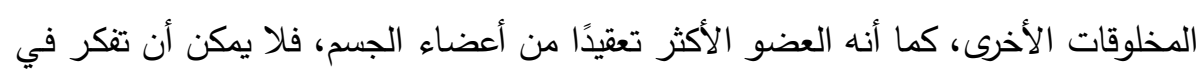
جهاز أعقد من الدماغ من حيث التركيب والوظيفة، فهو يحوي ملايين بل بلايين من الخلايا

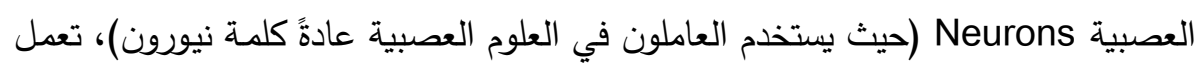

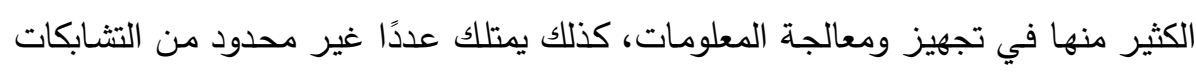
العصبية لهذه النيورونات، مما يسمح بتبادل المعلومات. إن نمط هذه التشابكات العصبية

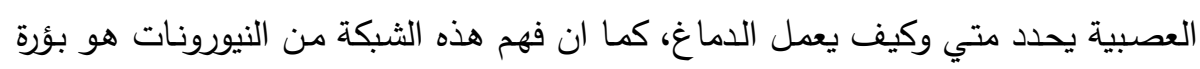
الهدف لعلم النفس العصبيى Neuropsychology. وتتتاول الورقة البحثبة الحالية بناء وتكامل القدرات الدماغية لدى فئات متباينة من أفراد

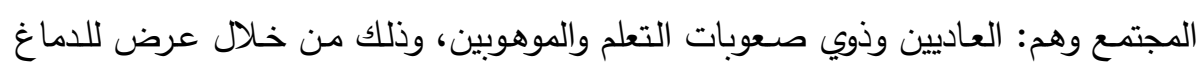

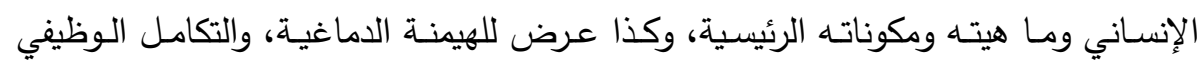


״

لجانبي الدماغ الإنساني، وأخيرًا تقديم عرضًا للدراسات والبحوث العربية التى تتاولت التكامل

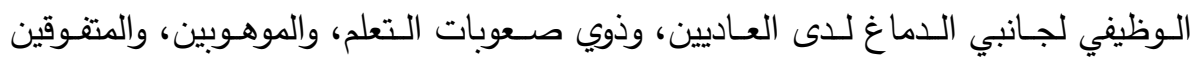

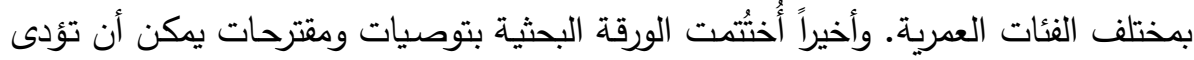

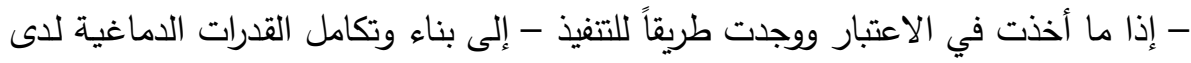
العاديين وذوى صعوبات التعلم والموهوبين والمتفوقين في إطار تطوير البنية العقلية من أجل تمكين الإنسان المصري والعربى.

كلمات مفتاحية: الدماغ الإنساني- القدرات الدماغية- صعوبات التعلم- الموهبة- التقوقالسيكوفسيولوجيا- النيوروسيكولوجيا - معالجة المعلومات. 


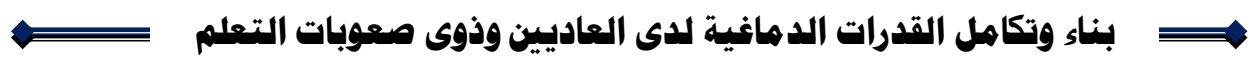

بناء وتكاهل القدرات الدهاغية لدى العاديين وذوى صعوبات التعلم

والموهوبين والالتفوقين

في إطار تطوير البنية العقاية هن أجل تمكين الإنسان الصري والعربي

"رؤية سيكوفسيولوجية ونيوروسيكولوجية للمعالجة المعلوهاتية" (ورقة عمل)

إعـداد

د/ أهل همهد غنايم

هدرس التربية الخاصة

قسمي التربية الخاصة

كلية التربية - جامعة قناة السويس

\author{
د/ سليسمان عبدالواحد يوسف \\ دكتوراه صعوبات التعلم \\ كلية التزبية - جاهعة قناة السويس \\ استاذ صعوبات التعلم المساعد \\ كلية التربية - جاهعة جازان - السعودية ” سابقاً"
}

همقدمهـة:

يُعتبر الدماغ الإنساني" Human Brain بنيـة ووظيفة أعظم من أيـة آلـة أخرى عرفها

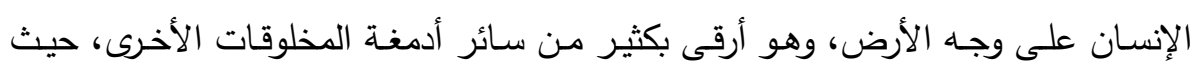

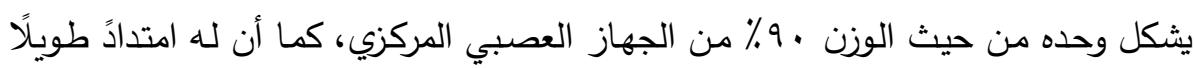

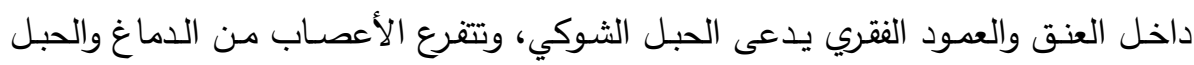

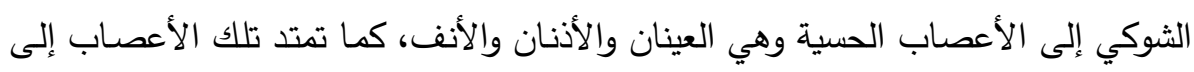

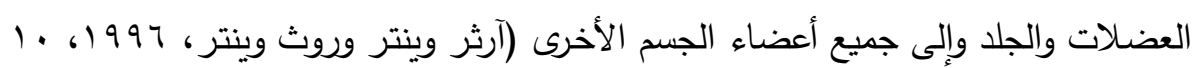

() ( )

ويمتلك الدماغ الإنساني القدرة على أن يوجها ويتحكم فى أنظمة حياتتا المختلفة، فيستقبل

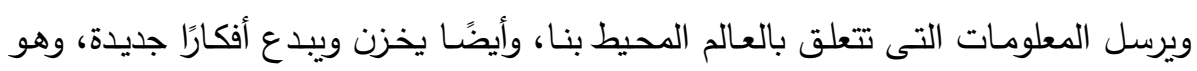

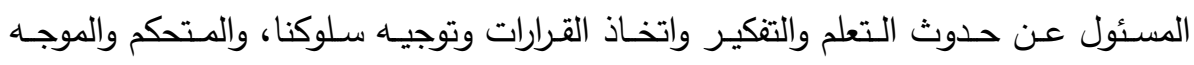

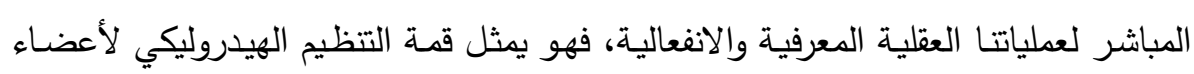

(") (") الدماغ والمخ (Brain)، وجانبي الدماغ، ونصفي المخ مصطلحات مترادفة فى هذه الورقة البحثية.

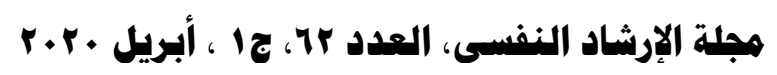


ב

الجسم. ولكننا بالرغم من كل ذلك فإننا نجهل العديد من المعلومات حول الوظائف التي

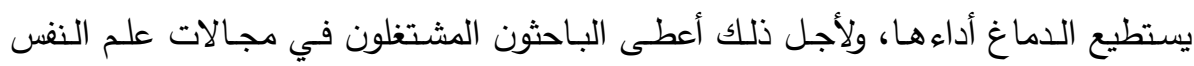

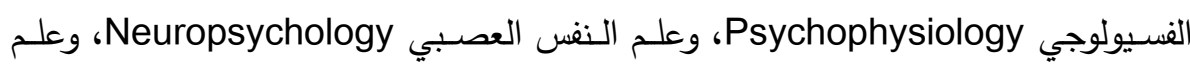
النفس المعرفي Cognitive Psychology أهمية كبيرة للمبادئ والكيفية التي يعمل بها المتخ، ولقد اهتمت الكثير من البحوث العلمية بكيفية عمل المـخ، وحديثًا اهتم بهذه الكيفية Cognitive

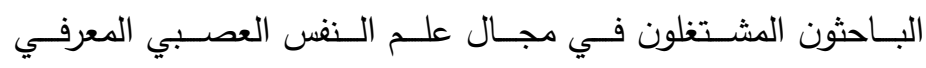
Neuropsychology

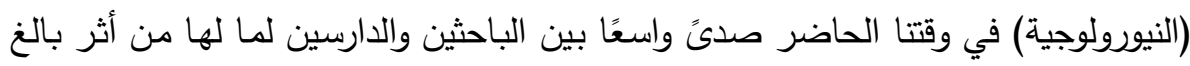

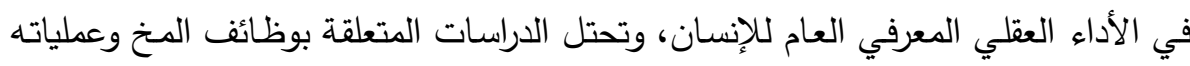

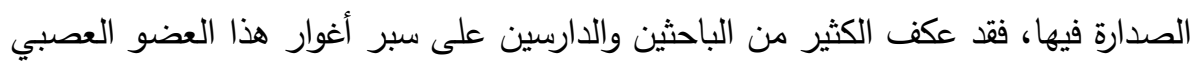

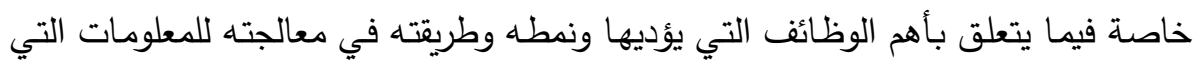

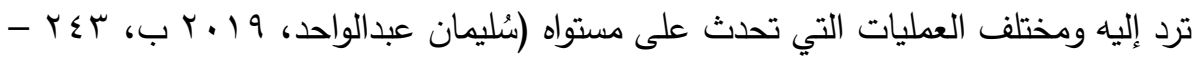

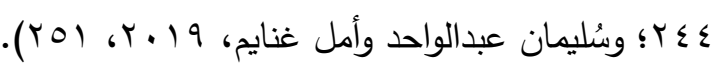
ولقد سُمي العقد الأول من القرن الحادى والعشرين بـ "عقد الدماغ"، حيث توسعت أبحاث الدماغ في نهاية القرن العشرين وذلك بسبب ظهور التتنيات الحديثة التي أتاحت للعلماء فرص سبر مناطق في الدماغ طالما ترك شأنها للتخمين، ولم يتمكن أي بحث من استثارة

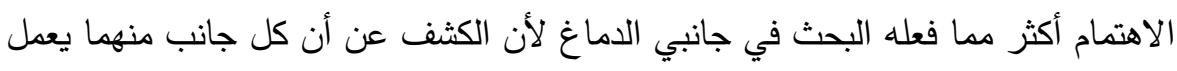

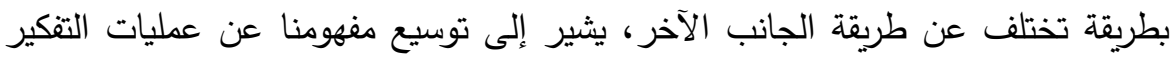
التي تميل إلى العمليات اللفظية التحليلية، ونحن نملك الدليل الآن على أن هذا التئين التركيز

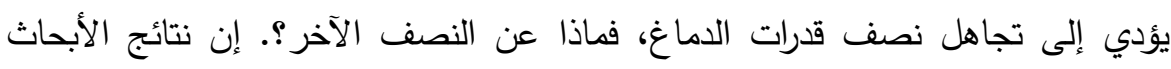
الحديثة المتعلقة بجانبى الدماغ وبعلم النفس العصبى المعرفى والفسيولوجى جعلتنا نعي أننا نمتلك أسلوبين مختلفين ولكنهما متكاملبن في معالجة المعلومات" : أحدهما مكانى ومتزامن

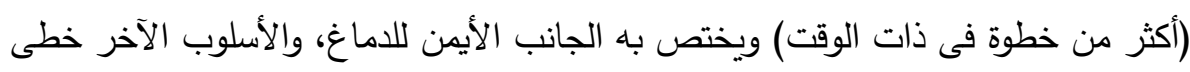

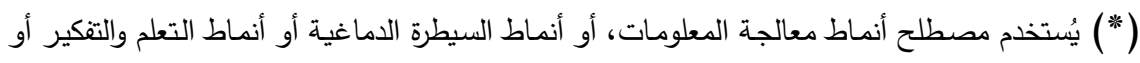

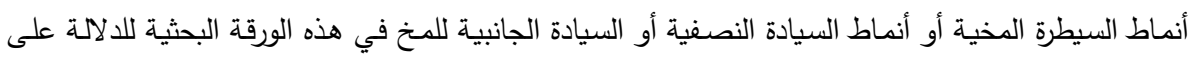

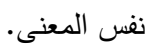

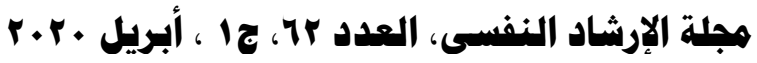


(خطوة تلو الأخرى) ويختص به الجانب الأيسر للدماغ، وقد أثار هذا الأكتشاف اهتمام

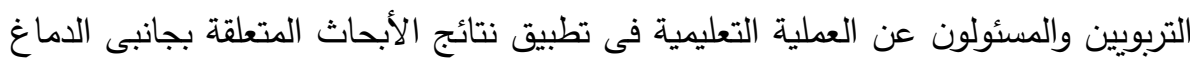
فى البيئة التعليمية داخل حجرات أو قاعات الدراسة. وفى الآونة الأخيرة تعالت الأصوات مطالبة بضرورة التغيير فى النظام التعليمى نتيجة لتراكم

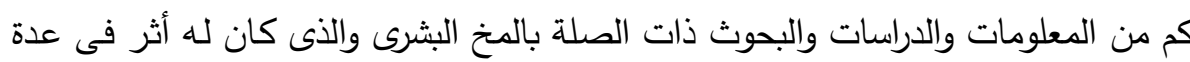

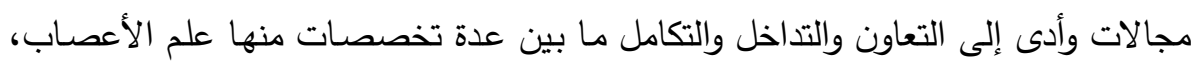

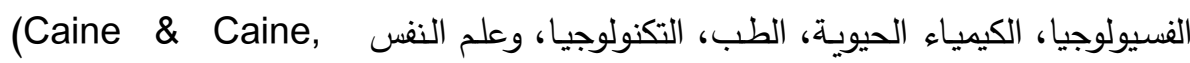

ونتيجة لأبحاث المخ الأخيرة والتى كان لها الأثر فى التخصصات السابق ذكرها فقد شجع

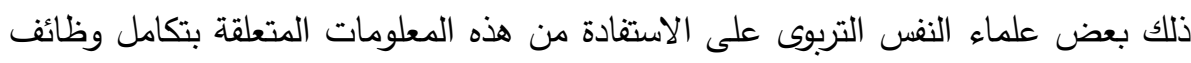

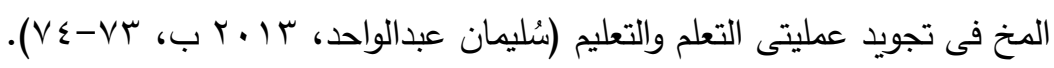

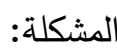

إن المتتبع لـلأدب السيكولوجى مـن دراسـات وبحوث تتاولت الدماغ الأيمـن والأيسر بـين الهيمنة والتكامل الوظيفي في مجال علم النفس في العقدين الأخيرين والتي تتاولتها سواء بالقياس، أو كتدخل سيكولوجي وتربوي، يلحظ مدى الاهتمام المنصب على دراسـة أنماط

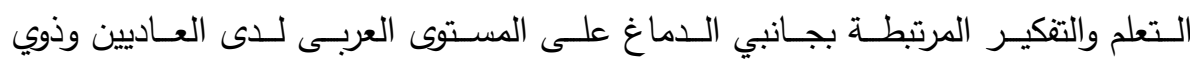
الاحتياجات الخاصة بمختلف المراحل العمرية، حيث اهتم جزء من هذه الدراسات والبحوث

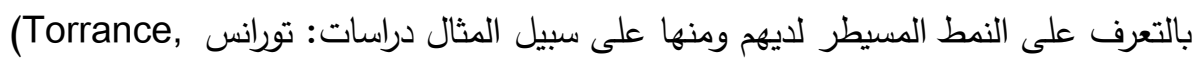
(Reynolds, \& Torrance, 1978)، 1975; 1981، ورينولدس وتورانس ومراد (Torrance \& Mourad, 1979)، وتورانس وأوكاباياشي \& \&

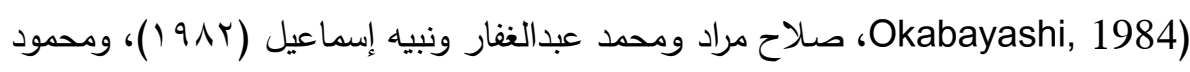

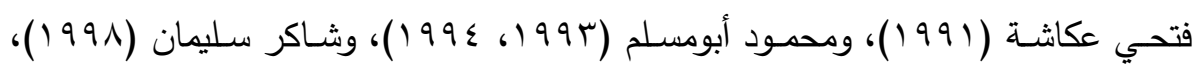

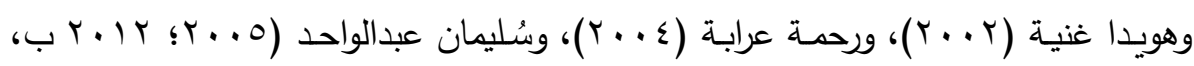

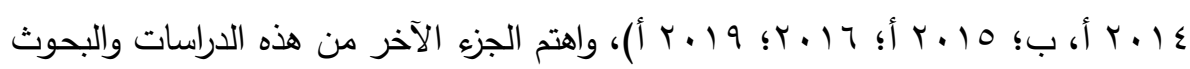
بتتميـة وظـائف جـانبي الدماغ معًا (نمط معالجـة المعلومـات المتكامل) مس خــلال بـرامج

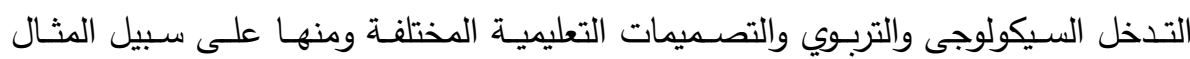

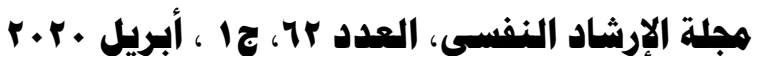




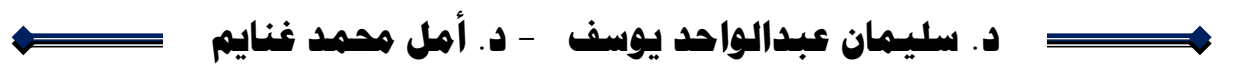

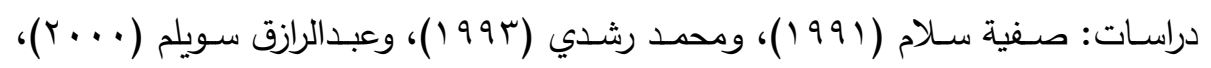

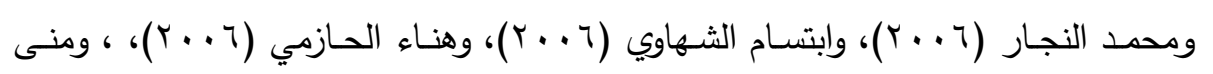

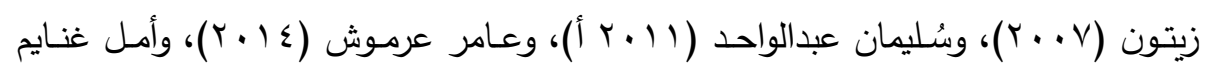

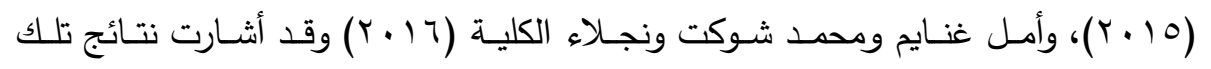
الدراسات إلى أهمية القدرات الدماغية (وظائف جانبي الدماغ) سواء من حيث الدئ ارتباطاتها

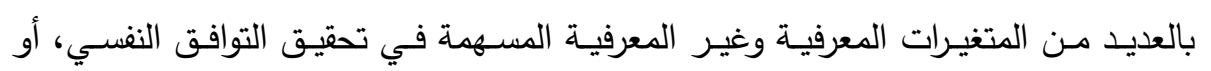

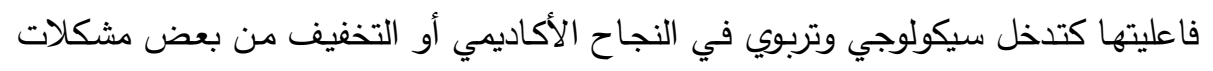
التعلم. ومن خلال ما تقدم يتضـح الاهتمام المتزايد بالبحث في القدرات الدماغية (وظائف جانبي

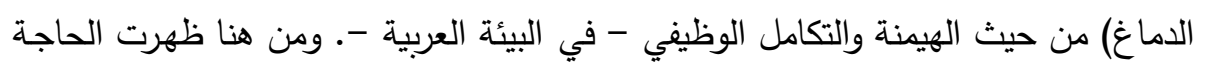

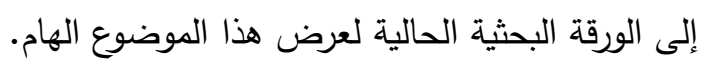

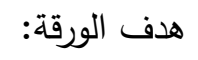

يتلخص هدف الورقة البحثية الحالية فى بناء وتكامل القدرات الدماغية لدى فئات متباينة من

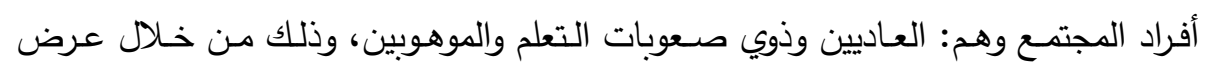

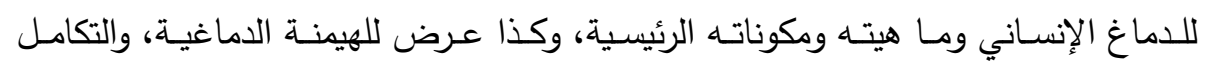

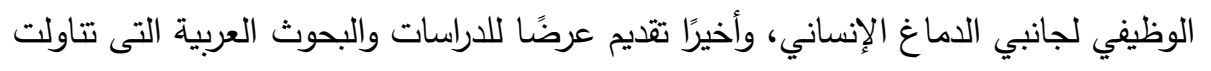

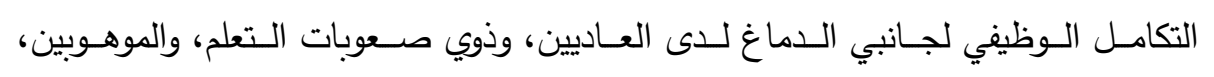
والمتقوقين بمختلف الفئات العمرية من أجل تمكين الإنسان المصري والعربي بالقرن الحادي ودي ولئي والعشرين.

\section{أهمية العشرين:}

تتحدد أهمية الورقة البحثية الحالية من خلال ما يلي:

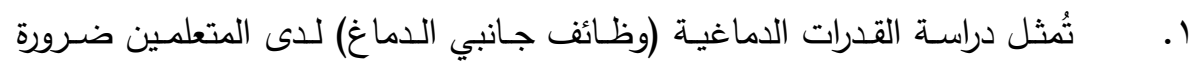
هامة، حيث تعد بعداً هاماً يسهم في تحقيق أهداف العملية التربوية، وتدعم في المتعلم القدرة على مواجهة التغييرات السريعة التي تطرأ على المجتمع في كافة جوانب الحياة المختلفة. 
r. يمكن أن تسهم دراسـة القدرات الدماغيـة (وظـائف جانبي الدماغ) في تحقيق أهم الأهداف الرئيسية للتربية ولدى المشتغلين بالبحث في مجال تتمية وظائف الدماغ الإنساني

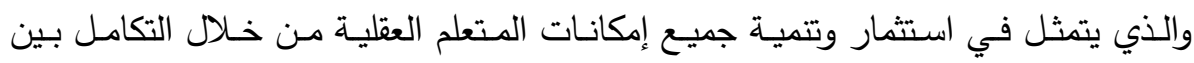

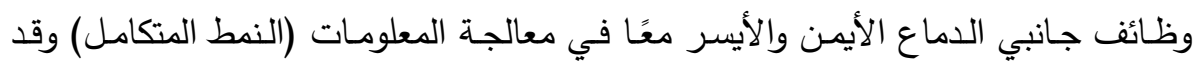

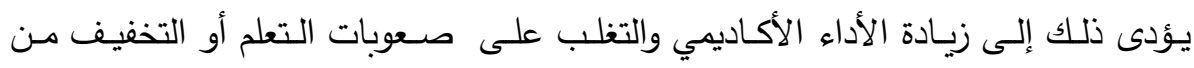
حدتها. المفاهيم الأساسية والدراسات السابقة:

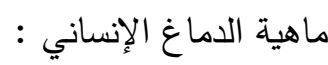

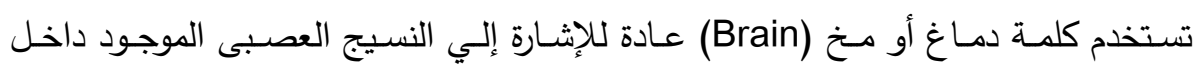
الجمجمة، كما تستخدم نفس الكلمة للإثشارة إلي ترجمة (Cerebrum) ويزن الدماغ لماغ الإنساني

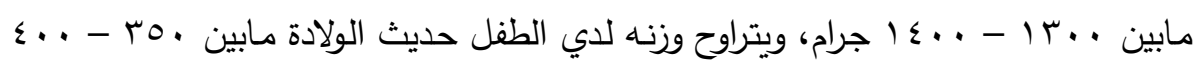

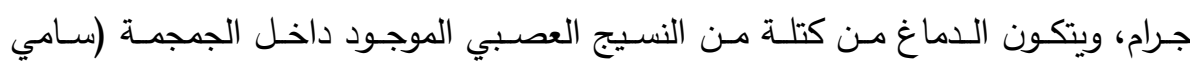

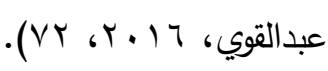

الاماغ الإنساني ومكوناته الرئيسية:

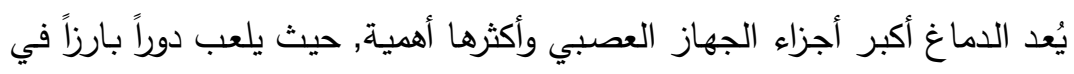
كثير من الوظائف النفسية والفسيولوجية والجوانب السلوكية المتعددة التي يقوم بها الإنسان

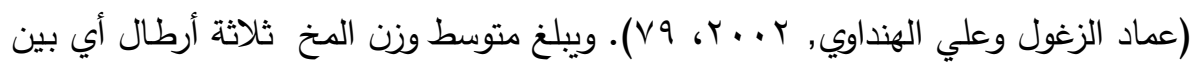

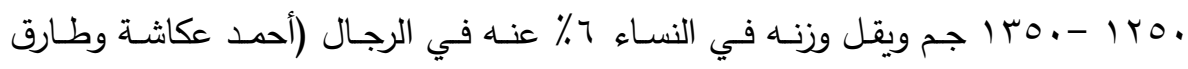

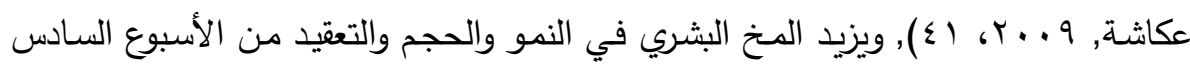

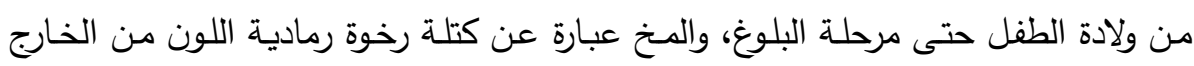

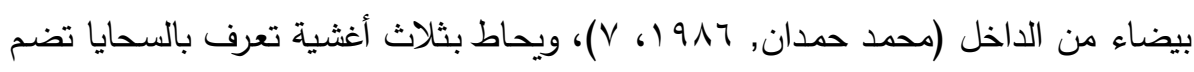

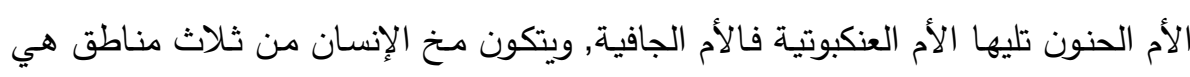

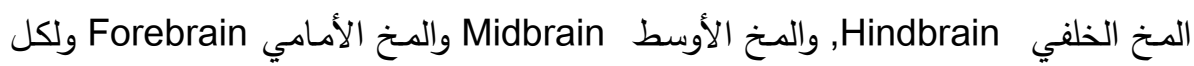

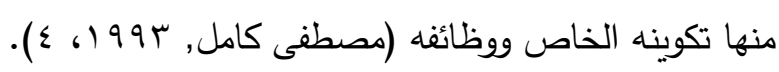


$\Longleftrightarrow$

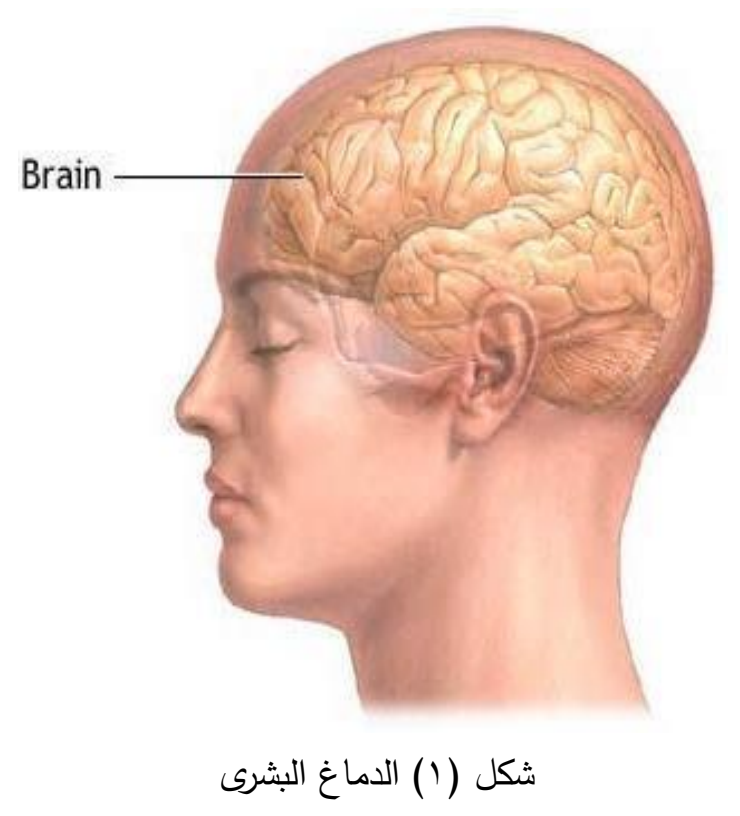

ويمكن تقسيم جـانبى الـماغ إلى أربعـة أقسـام رئيسـية تسـمي الفصـوص Lobes وهـذه

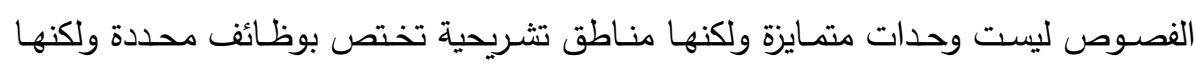

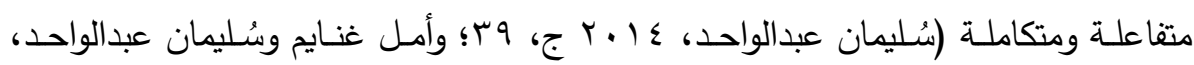

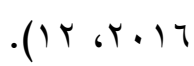
ويمكن توضيح فصوص الدماغ الأربعة المكونة للنصفين الكرويين بالثكل التالي: 


\section{$\Longleftrightarrow$}

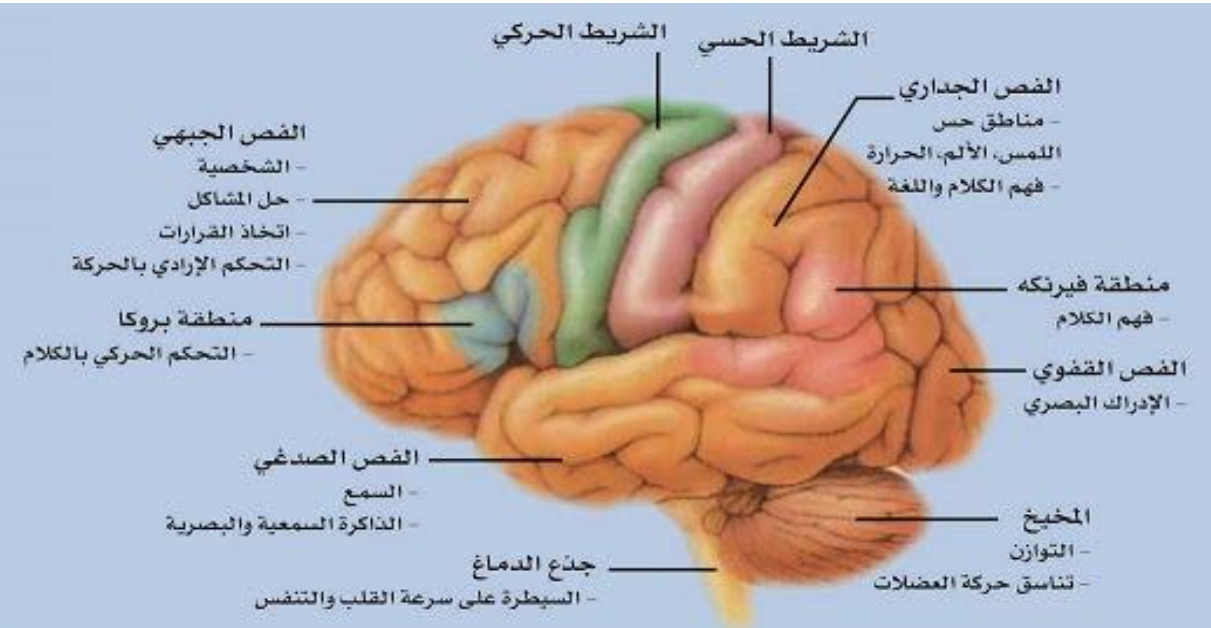

شكل (Y) فصوص الدماغ الأربعة المكونة للنصفين الكرويين

وسوف يتتاول الباحثان فصوص المخ الأربعة المكونة للنصفين الكرويين للدماغ، وما تحتويه

من مراكز هامة ترتبط بالعمليات العقلية المعرفية، وذلك في السطور التالية:

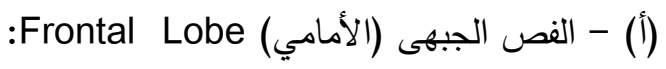

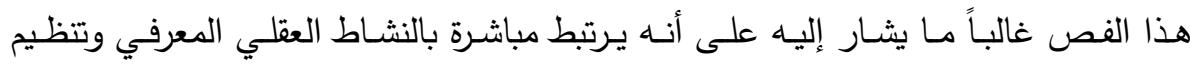

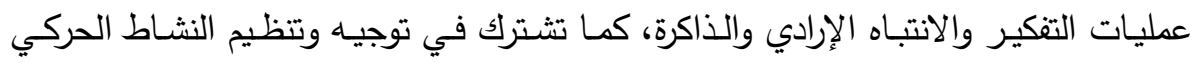

$$
\begin{aligned}
& \text { (عبدالوهاب كامل، ع . . Y، هץ I - צr I I). } \\
& \text { (ب) - الفص الجداري Parietal Lobe: }
\end{aligned}
$$

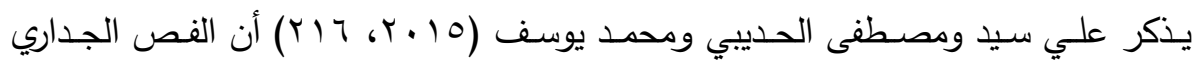
يختص بتجهيز ومعالجة المعلومات الواردة عن طريق الحواس الجسدية كالجلد والعضـلات، وهذا الفص يختص بالانتباه للمثيرات، التكامل الحسي، والتوجـه، وإدراك وضسع الجسم في

(ج) - الفص الصدغي :Temporal Lobe

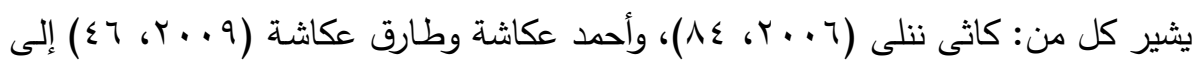

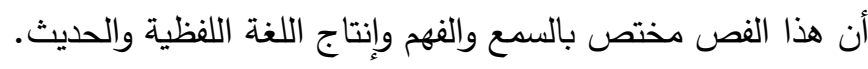




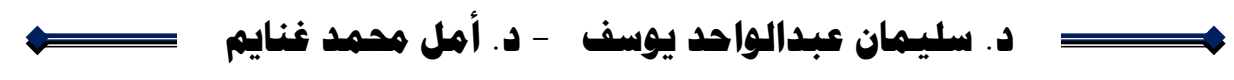

(د) - الفص القذالى (الخلفي) Occiptal Lobe)

وهو مركز حاسة البصر حيث يستقبل الصور التي تلتقطها العين وتقوم بإدراكها وتقديرها وتقويمها، ويشير دانيال هالاهـان وجيمس كوفمان وجون لويـ ومارجريت ويس وإليزابيث

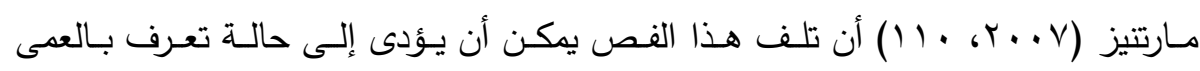
البصري Visual agnosia والتي تعنى عدم قدرة الفرد على إدراك الأشياء العامة حتى وإن لتصني كان يتمتع بحدة إبصار عادية.

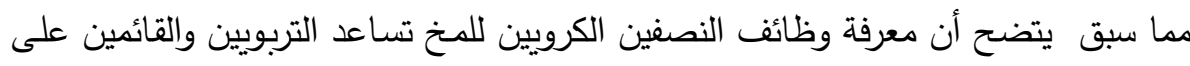

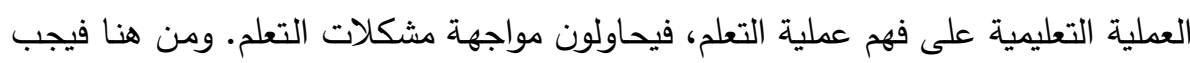
أن يكون المربيين والمعلمين على دراية ومعرفة بوظائف النصفين الكرويين للدماغ.

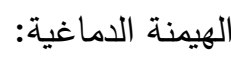
إن المخ الإنساني تركيباً ووظيفةً لا ينعزل عن سياقه الجسمي والوجداني والاجتماعي، فهذا

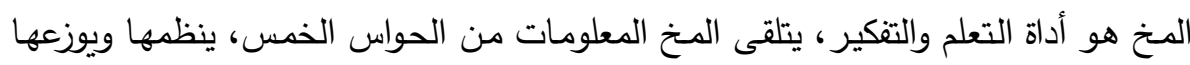

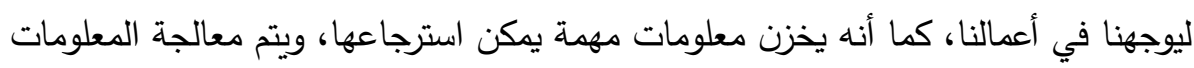

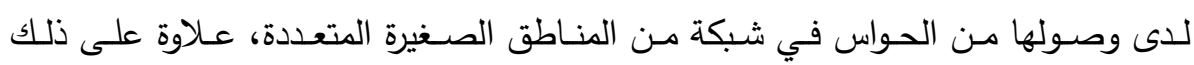
تتخصص منـاطق أخرى مـن القشرة المخيـة بدمج المعلومـات من حاستين أو أكثر فمثلاً

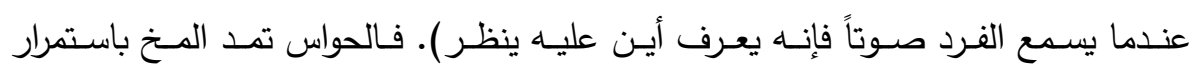

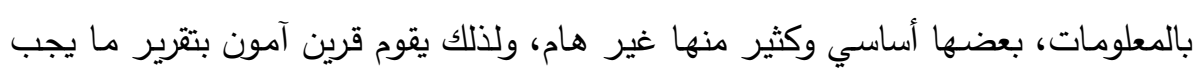

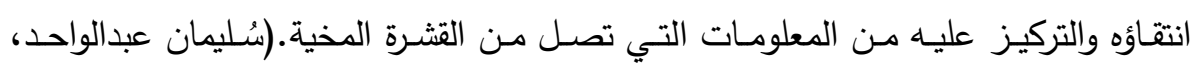
. (^

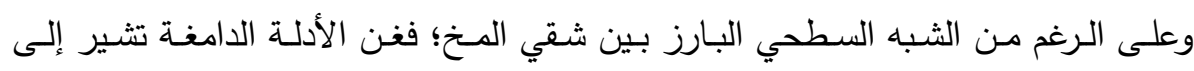

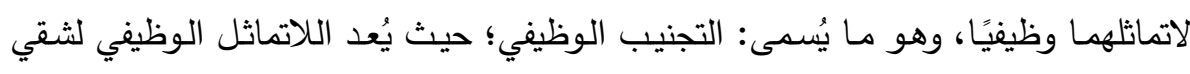

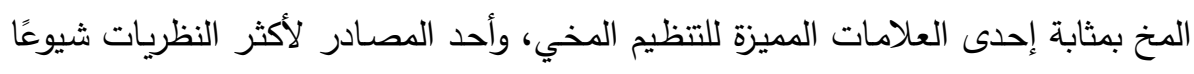

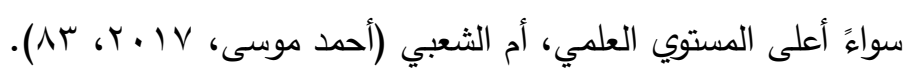

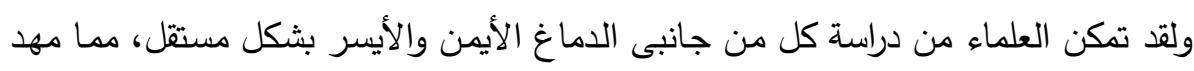

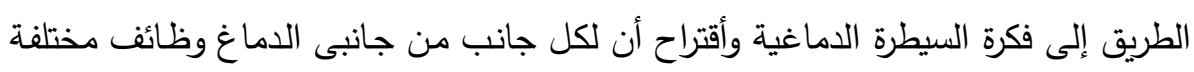

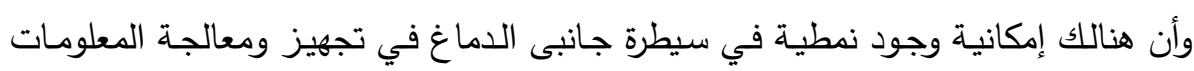

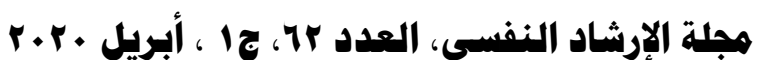


وعلى السلوك الإنساني، ويستخدم مفهوم السيطرة Dominance للتعبير عن تقسيم العمل

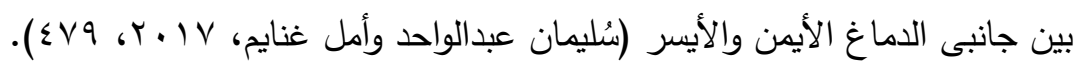

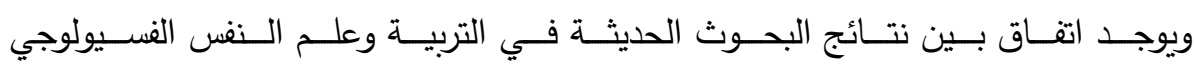

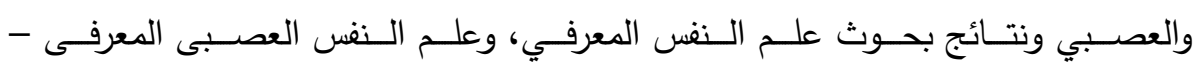

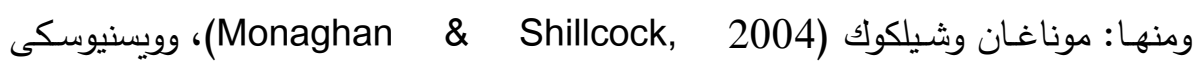

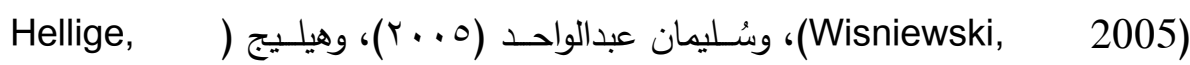

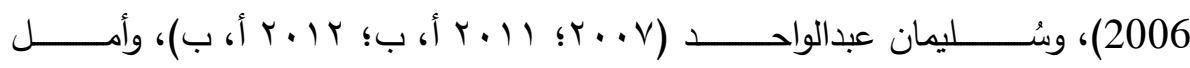

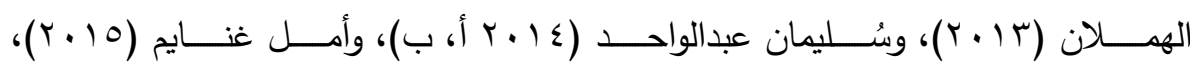

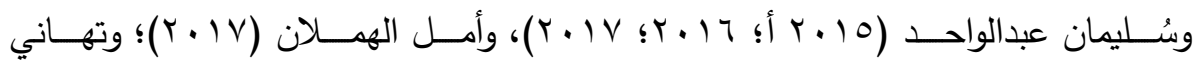

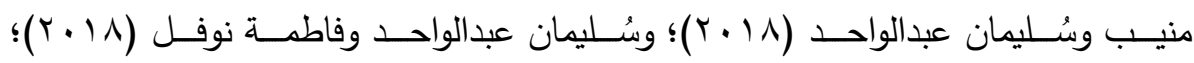

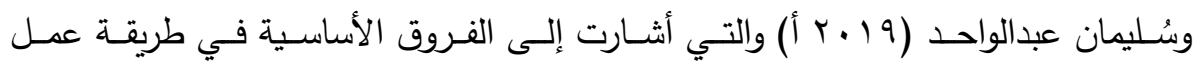

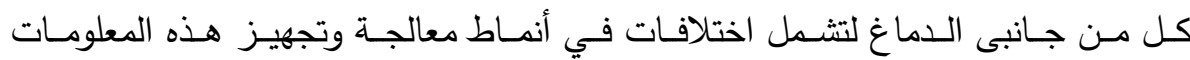

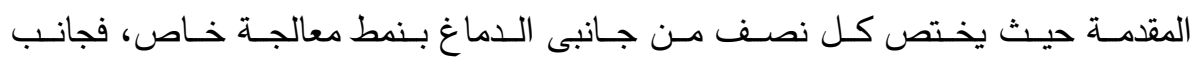

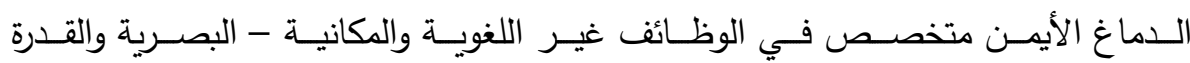

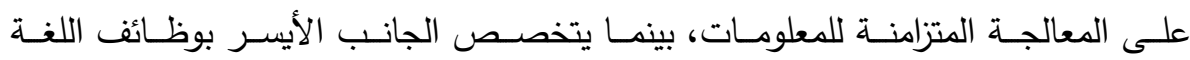

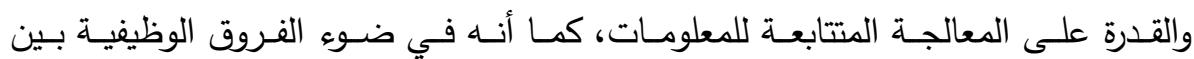

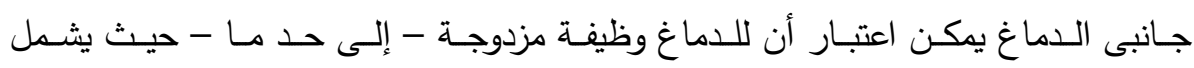

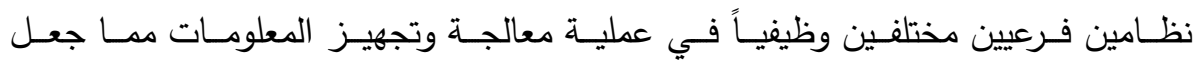

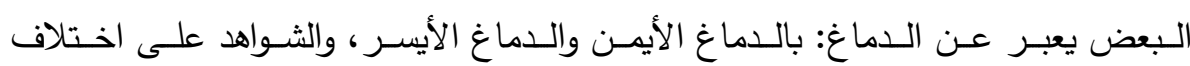

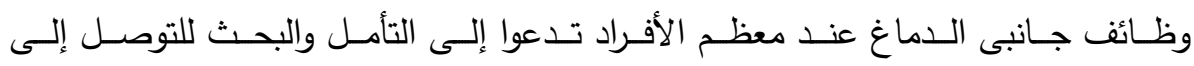

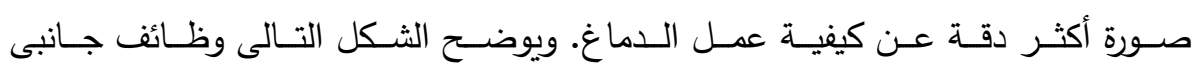

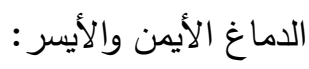




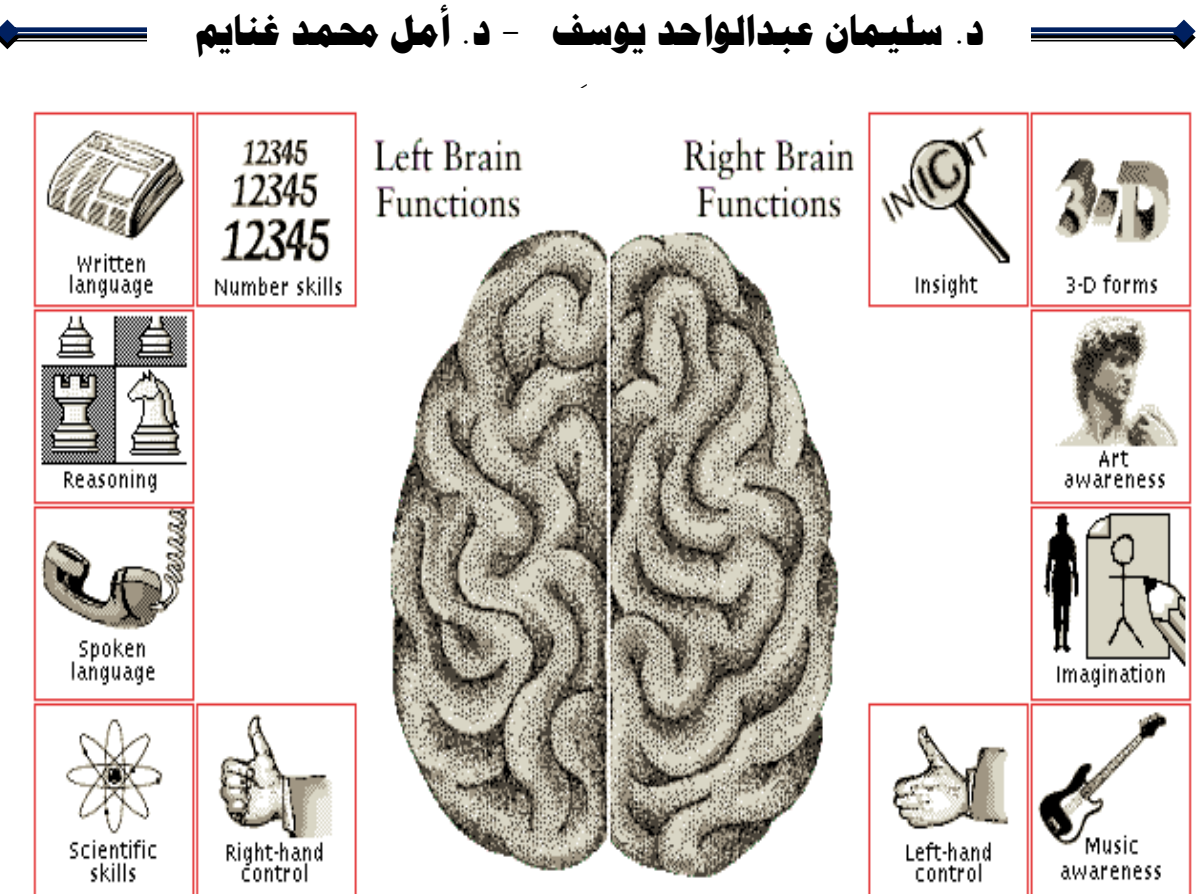

$$
\text { شكل (r) وظائف جانبى الدماغ . }
$$

وفى إطار اتجاه إزاحة السيطرة الدماغية وضرورة التكامل بين وظائف جانبى الدماغ تدعو

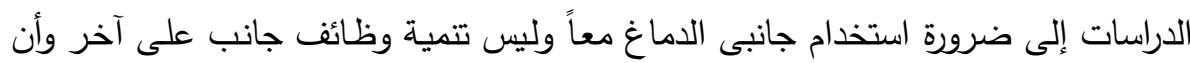

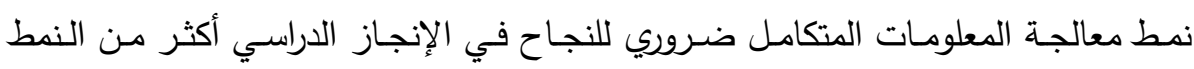

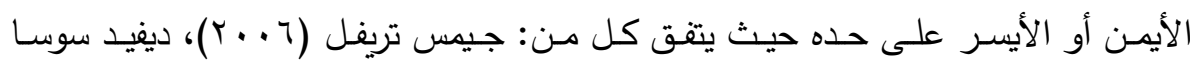

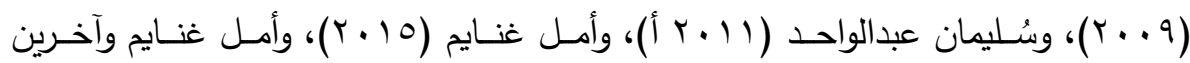

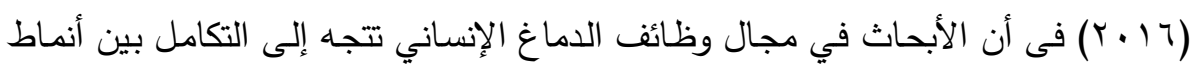
معالجة المعلومات المختلفة لدى المتعلمين حيث يؤدى جانبى الدماغ عملهما بتكاملية في

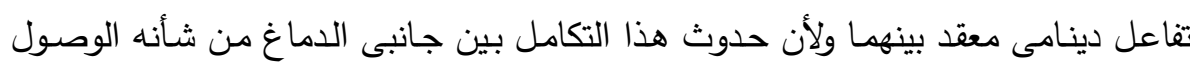

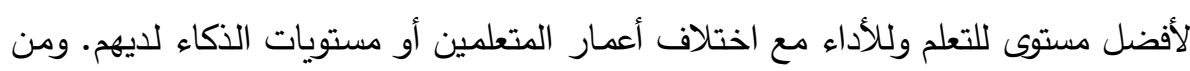

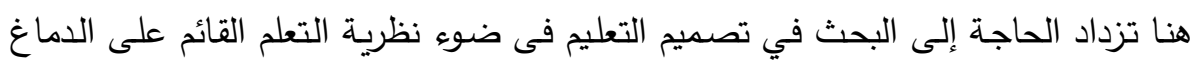

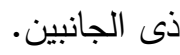

\section{التكامل الوظيفى لجانبى الدماغ الإنساني:}

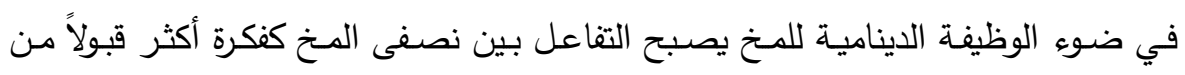

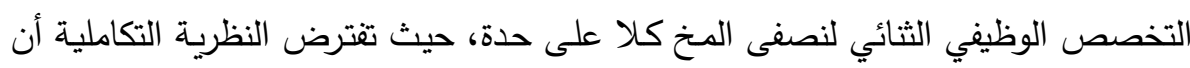

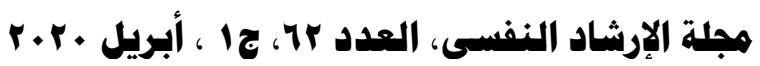


هناك طبيعة تكاملية للنصفين الكرويين بالمخ، وأنهما لا يعملان بمعزل عن بعضهما، بل

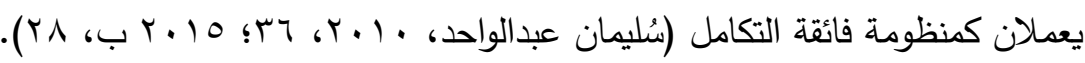

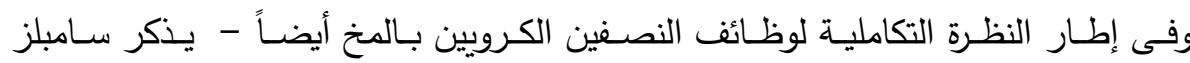

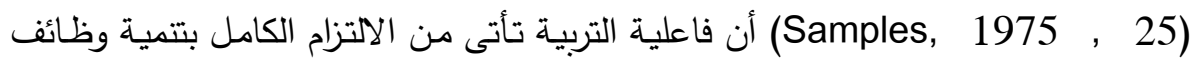
نصفى المخ معاً، لأن معظم أنثطة حياتتا تتطلب كلاً من نصفى المخخ معًا. ويؤكد كلارك وستار (Clark \& Star, 1991, 33) على أنه يجب قدر الإمكان أن نعمل على تشغيل

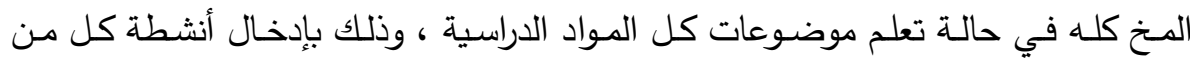
النصف الكروي الأيمن والأيسر معاً في عملية التعلم.

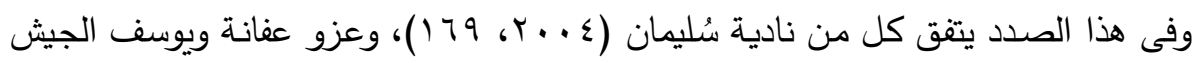

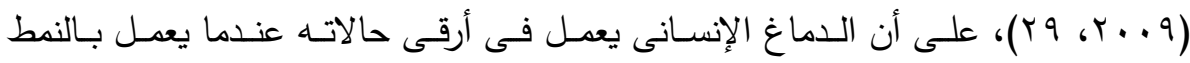

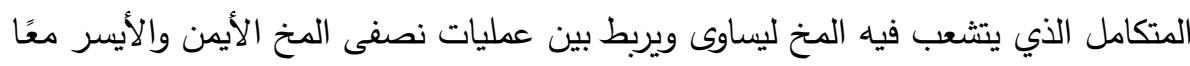
ولا يسيطر نصف على آخر . ولعل التركيز على عدم التماثل الوظيفي بين النصفين الكرويين هو الذي دفع البعض للقول لهرل

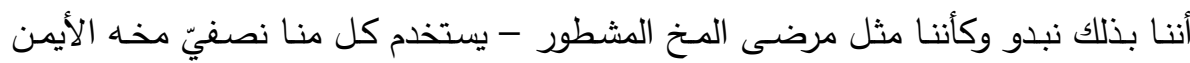

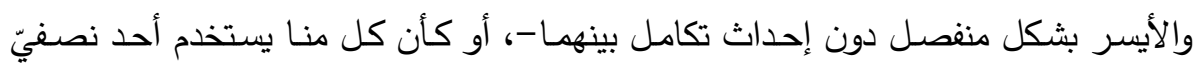
مخه فقط - إذا أخذنا بفكرة السيادة النصفية - ، وبدأ التركيز على محاولة التوصل للكيفية التي يعمل بها النصفان معاً. وأصبح الجدل قائماً حول مدى صحة تقسيم الوظائف العقلية

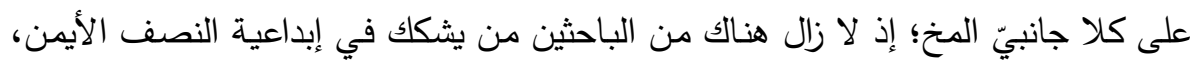
وتحليلية النصف الأيسر ، ويسوقون الدلائل على عدم صحة وجود وظائف محددة تماماً لكلا

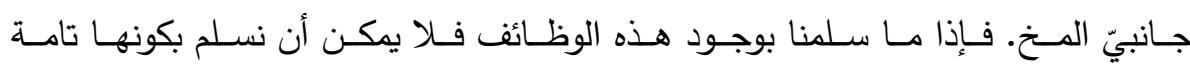

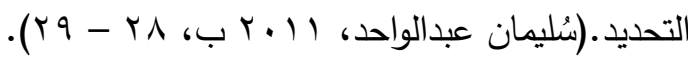
وإذا كان هناك من الباحثين من يدلل من خلال نتائج دراساتهم على صحة التقسيم النظري

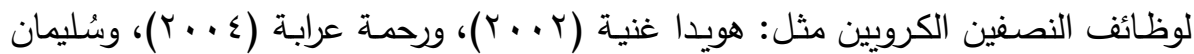

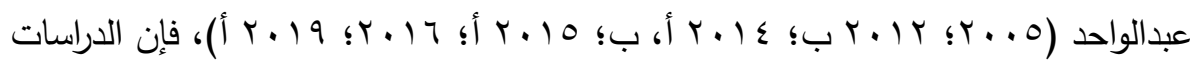
عن التلف المخي للموهوبين من المؤلفين الموسيقيين قد وجدت أن التلف لأي من الني النصفين

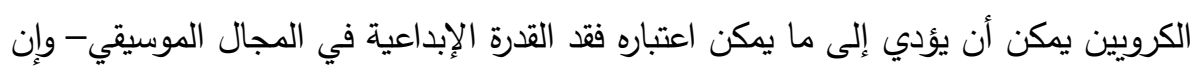

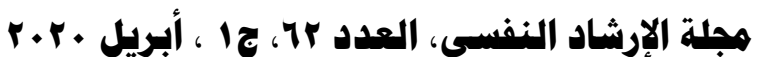




\section{د. سليهان عبدالواحد يوسف -د. أهل محمد غنايم}

كان الضعف يكون أعظم في حالة تلف النصف الأيمن-، ممـا يعد دليلاً على أن كـلا

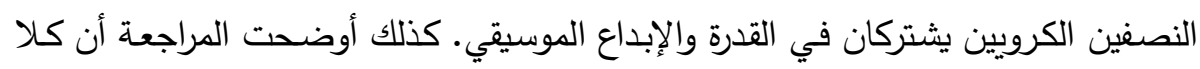

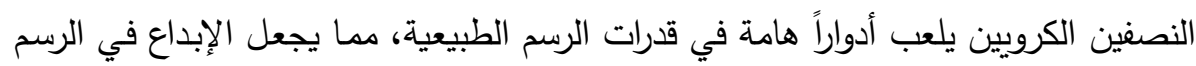

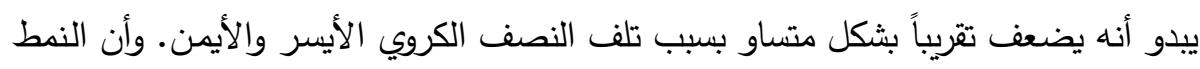

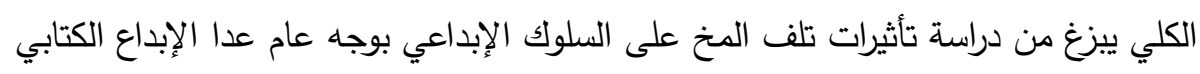

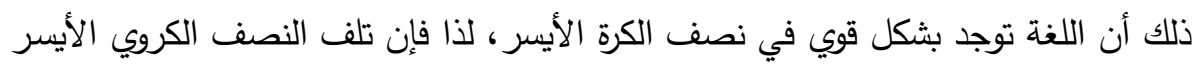

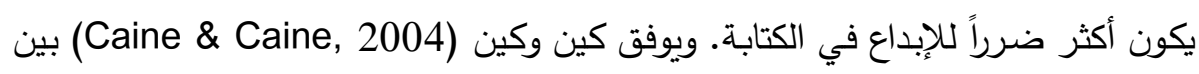

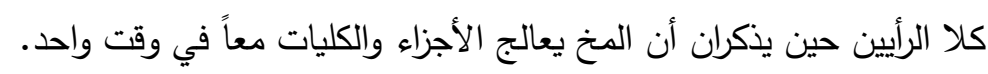

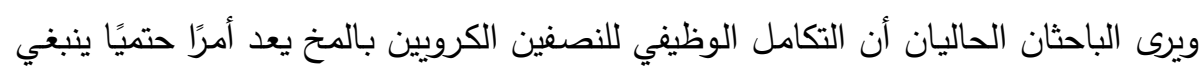

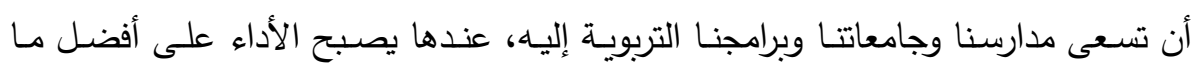

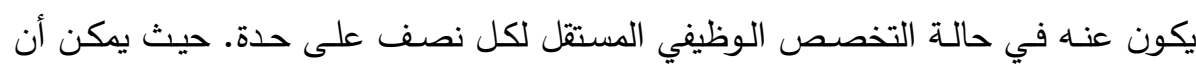

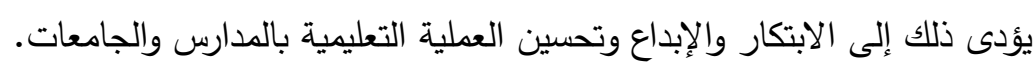

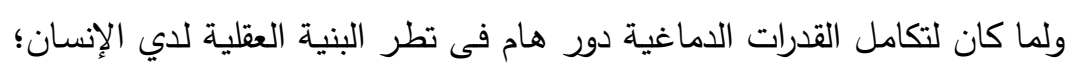

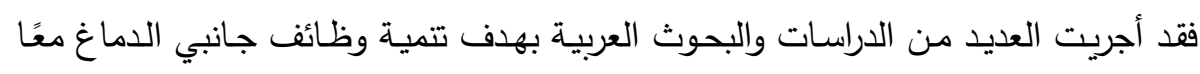

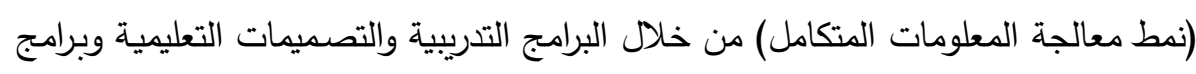

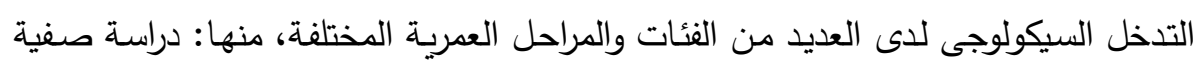

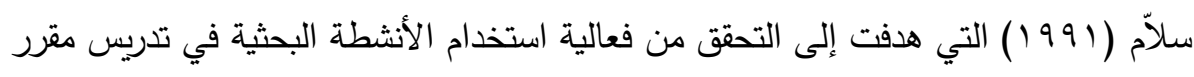

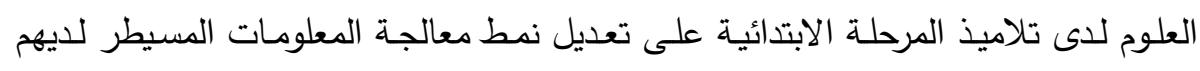

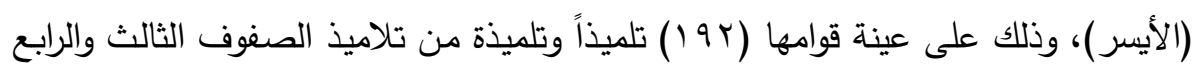

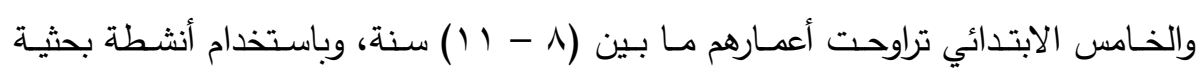

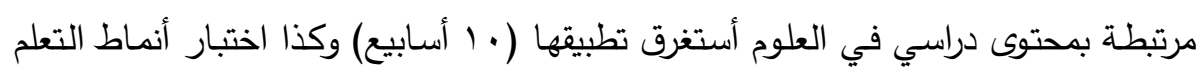

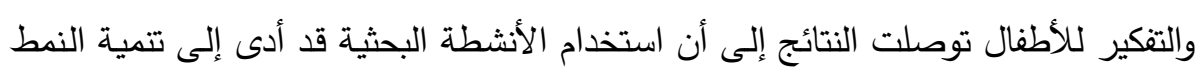
الأيمن والمتكامل لدى أفراد الدجموعة التجريبية.

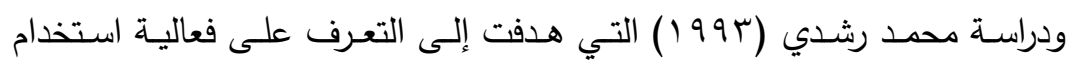

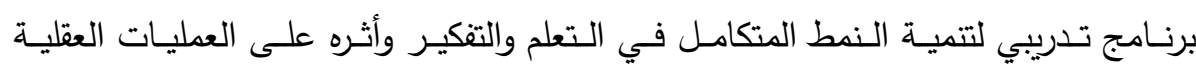

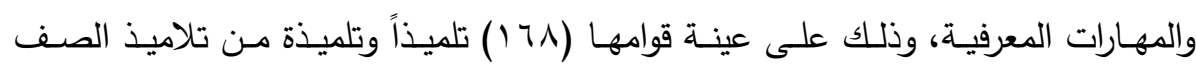

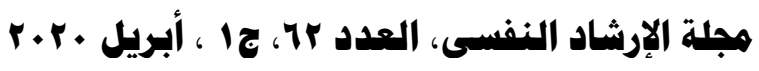


الخامس الابتدائي، وباستخدام برنـامج تدريبي معد في ضوء أنشطة وتمرينات تركز على

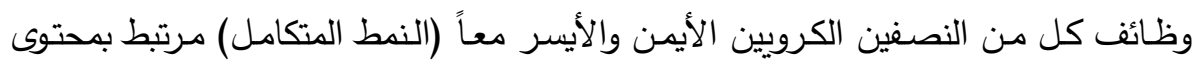

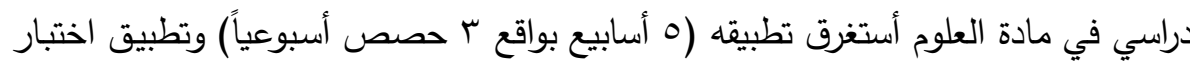

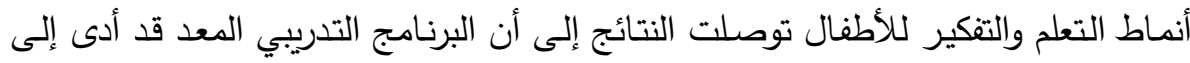
تتمية نمط معالجة المعلومات المتكامل لاى أفراد المجموعة التجريبية.

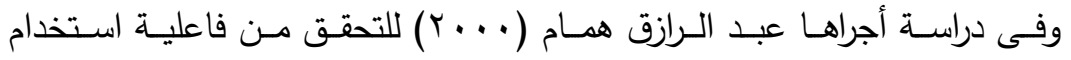

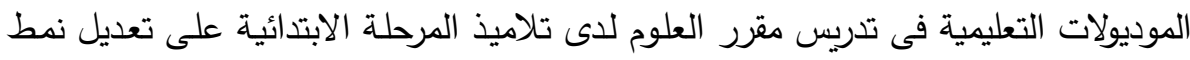
معالجة المعلومات المسيطر لديهم (الأيسر )، وذلك على عينة قوامها (17 ( ) تلميذاً وتلميذة مـن تلاميذ الصـف الخـامس الابتدائي، وباستخدام برنـامج تدريسي يعتمـد على استخدام

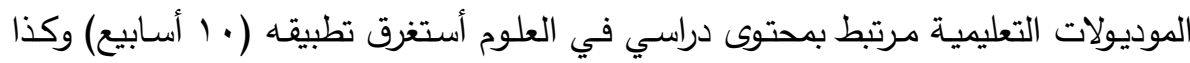
اختبار أنماط التعلم والتفكير للأطفال توصلت النتائج إلى أن استخدام الموديولات التعليمية دراتية أدى إلى تتمية نمط معالجة المعلومات المتكامل لاى أفراد المجموعة التجريبية. وقامت نعيمة حسن وسحر محمد ( ( . ب) بإجراء دراسة للكثف عن أثر استخدام التدريس بالمدخل البصري المكاني في تتمية النمط المتكامل في التعلم والتفكير، وذلك على التى

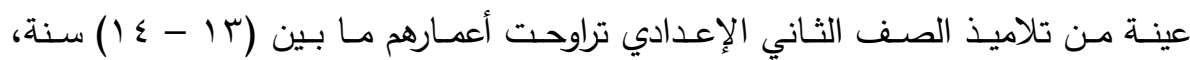
وباستخدام أنشطة بصرية مكانية تركز على التخيل المنظومى من خـلال الصور والرسوم

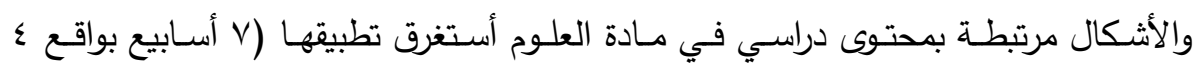

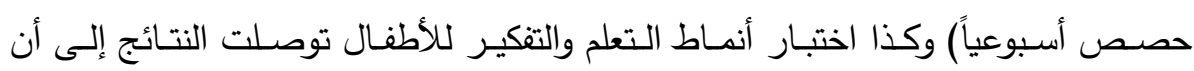

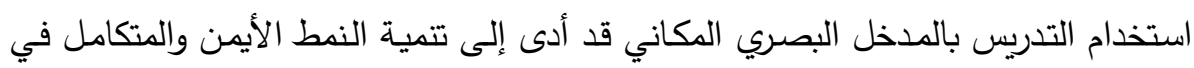
التعلم والتفكير لاى أفراد المجموعة التجريبية.

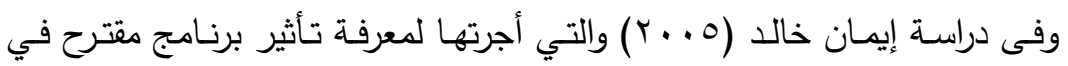

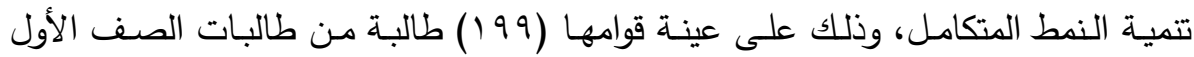

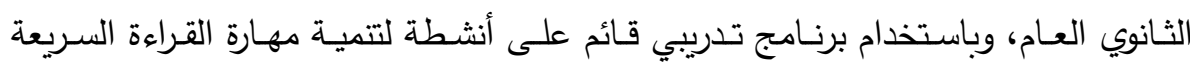

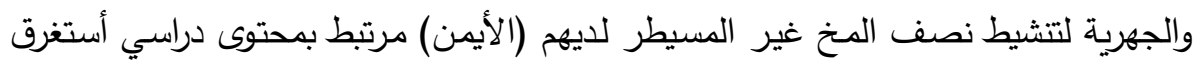

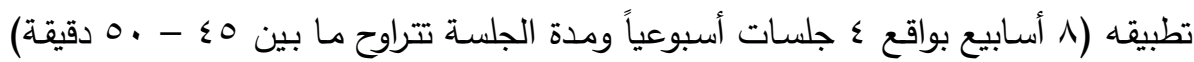




\section{״}

توصلت النتائج إلى فعالية البرنامج في تتمية نمط معالجة المعلومات المتكامل للى أفراد

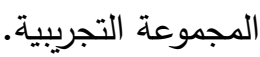

أما ابتسام الثهاوى (T T ) فقد أجرت دراسة للكثف عن فاعلية برنامج تدريبي في زيادة النمط المتكامل للتفكير وقياس أثره على تتمية القدرة على حل المشكلات، وذلك دلك

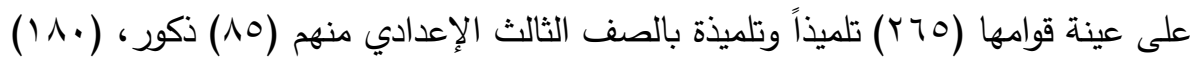

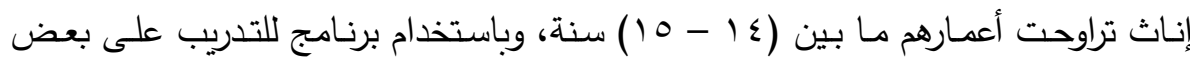
استراتيجيات حل المشكلات غير مرتبط بمحتوى دراسي أستغرق تطبيقه (0 أسابيع) توصلت الدراسة إلى أن التدريب على بعض استراتيجيات حل المشكلات أدى إلى استخدام النصفين معاً (النمط المتكامل).

وقامت هناء الحازمى (ך + . ب) بإجراء دراسة دراسة للكثف عن فاعلية استخدام

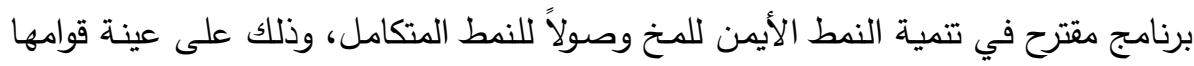
(70) طالبة من طالبات الصف الثانى المتوسط بالمدينة المنورة بالمملكة العربية السعودية، وباستخدام مقياس تورانس لأنماط التعلم والتفكير للصغار وكذا برنامج مقترح لتتمية النمط بالئه

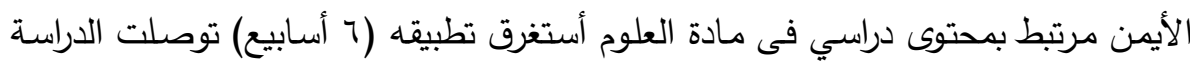

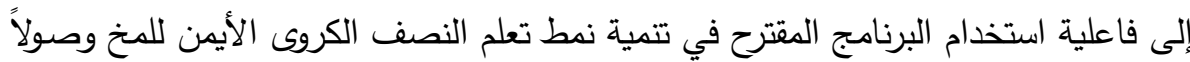

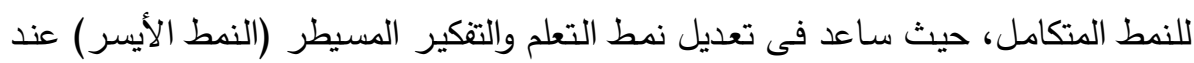
تالاطالبات وإثارة وتتمية النمطين الأيمن والمتكامل بصورة أفضل مما سبقل فئ.

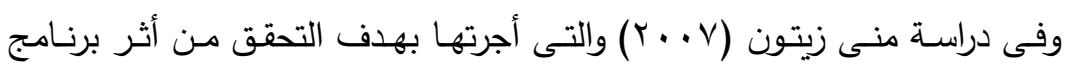
لتدريس العلوم متتوع الأنشطة على تتمية نمط التعلم والتتكير المتكامل ، وذلك على على عينة قوامها ( • 7 ) تلميذاً وتلميذة من تلاميذ وتلميذات الصف الثاني الإعدادي تراوحت أعمارهم

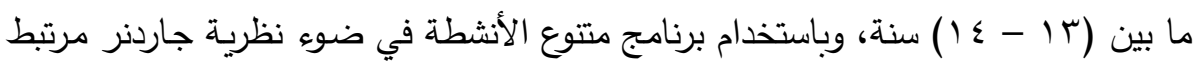

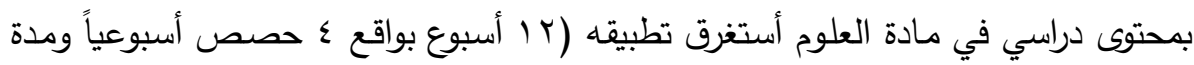

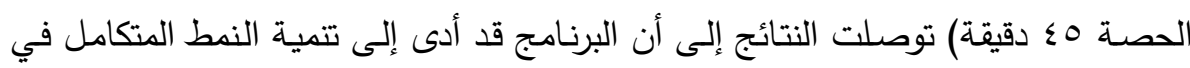
التعلم والتفكير لاى أفراد المجموعة التجريبية.

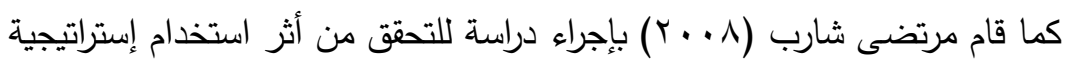

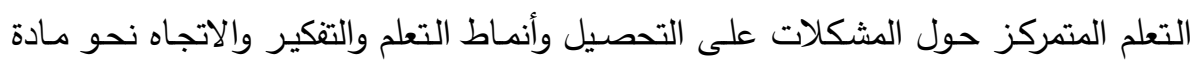

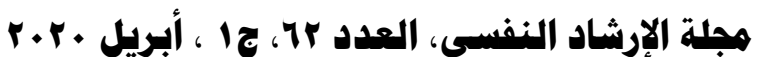


العلوم ، وذلك على عينـة قوامها (• ب ( ) تلميذاً من تلاميذ الصف الثانى الإعدادى بقريـة

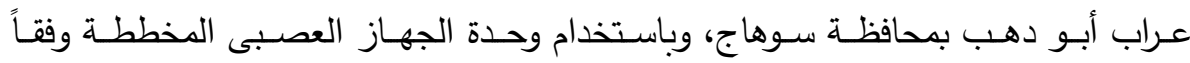
لإستراتيجية التعلم المتمركز حول حل المشكلات، وكذا اختبار تحصيلى فى وحدة الجهاز

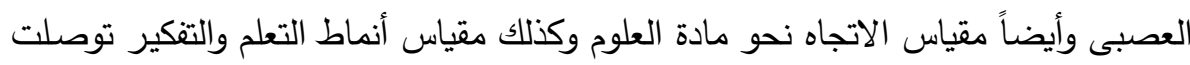
النتائج إلى أن استخدام إستراتيجية التعلم المتمركز حول المشكلات قد أدى إده إلى تتمية النمط المتكامل في التعلم والتفكير لدى أفراد المجموعة التجريبية.

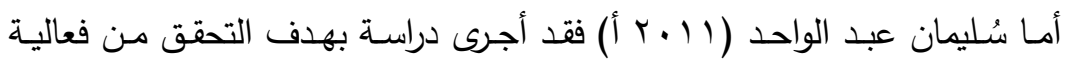

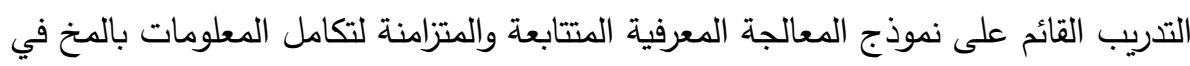

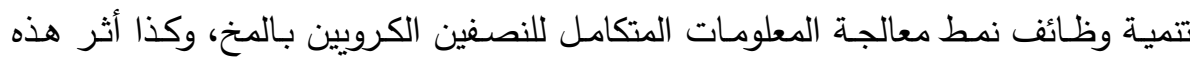

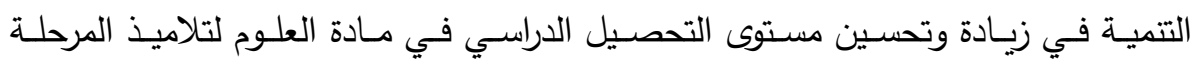

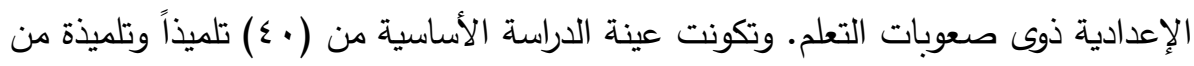

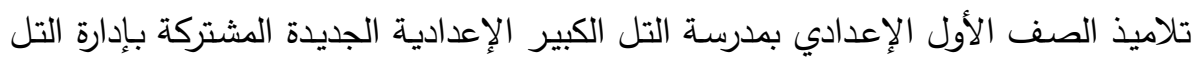

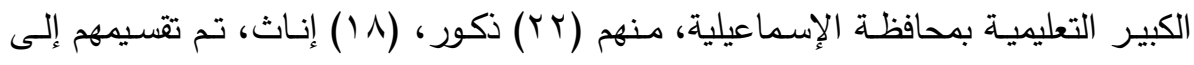
مجموعتين أحدهما تجريبية والأخرى ضـابطة وقوام كل مجموعـة (1) (1 ذكور ، 9 إنـاث)، وبتطبيق أدوات الدراسـة والتي تضمنت (اختبار التحصيل الدراسي في مـادة العلوم إعداد/ الباحث، واختبار كاتل للذكاء "المقياس الثاني - الصورة (أ)"، ومقياس المستوى الاجتماعي لتوني

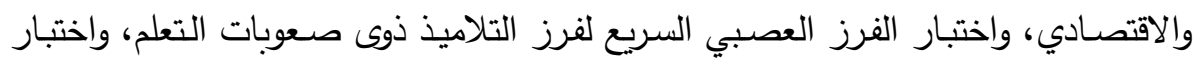
أنماط التعلم والتفكير (الصورة أ)، بالإضافة إلى البرنامج التدريبي باستخدام الكمبيوتر لتتمية لتصنية

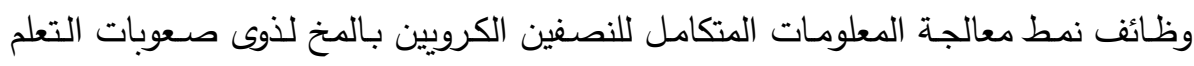
إعداد/ الباحث، وبإتباع المنهج شبه التجريبي وكذا باستخدام أساليب المعالجة الإحصائية

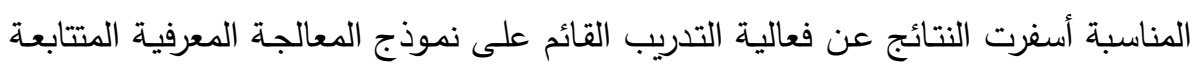

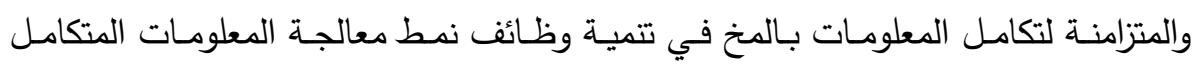

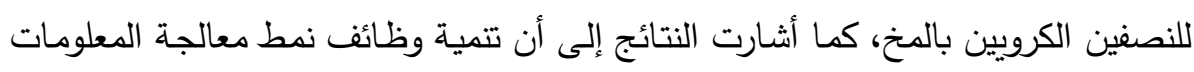
المتكامل أدت إلى زيادة وتحسين مستوى التحصيل الدراسي في مادة العلوم لتلاميذ المرحلة

$$
\text { الإعدادية ذوى صعوبات التعلم. }
$$

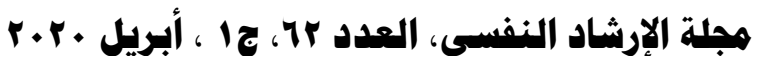




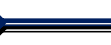

- مـ أهل محمد غنايم

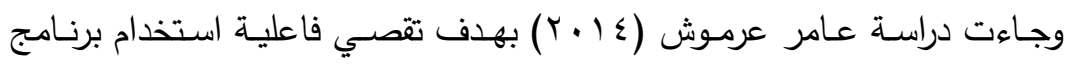

مقترح في تتمية نمط التعلم المتكامل للدماغ لدى طلاب الصف السابع الأساسي في مدارس وكالة الغوث بمدينة عمّان بالمملكة الأردنية الهاشمية، وتكونت عينة الدراسة من ( • ؟) طالبًا تم تقسيمهم إلى مجموعتين احدهما تجريبية والأخرى ضابطة، وبتطبيق برنامج مقترح لتتمية بالية

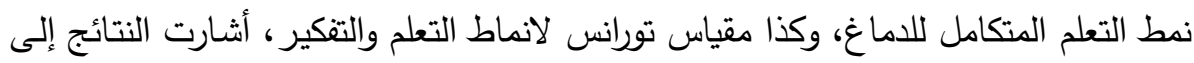

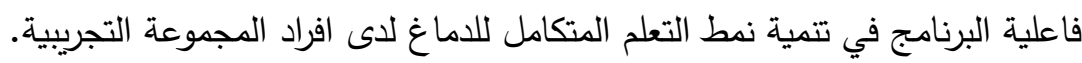

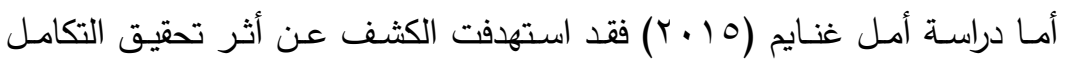
الوظيفى بين نصفى المخ الكرويين فى تتمية القدرة على التفكير الإبداعى لدى المتفوقين من

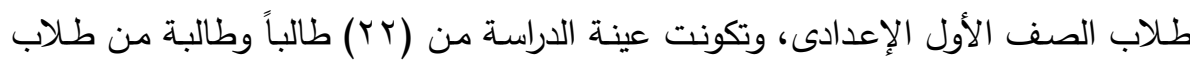

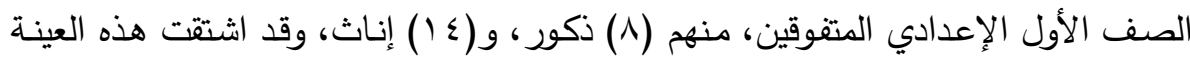

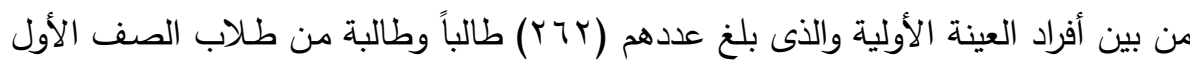

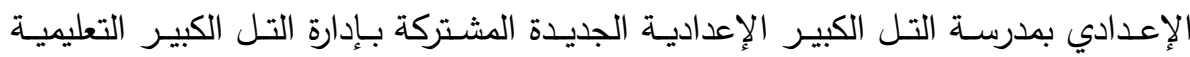

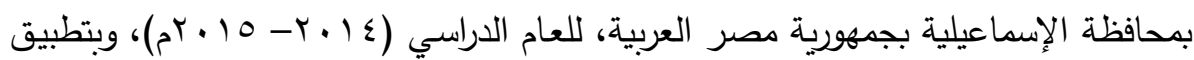

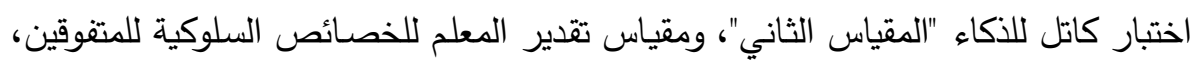
واختبار أنماط التعلم والتفكير الصورة (أ)، واختبار القدرة على التفكير الإبداعي باستخدام

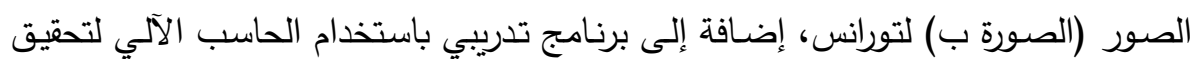

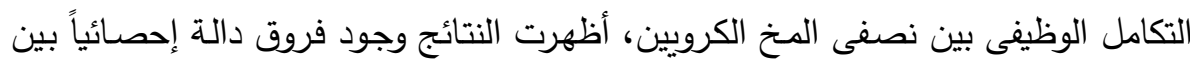
متوسطات رتب طلاب المجموعة التجريبية في القياسين القبلي والبعدي على مقياس القدرة

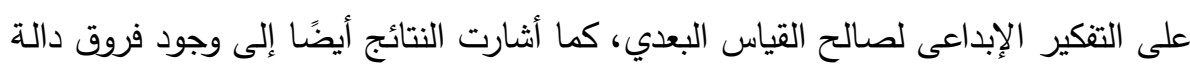

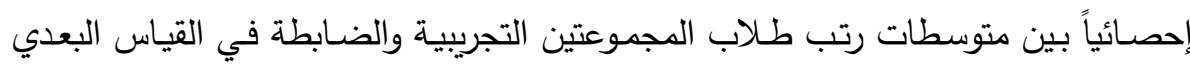
على مقياس القدرة على التفكير الإبداعى لصالح أفراد المجموعة التجريبية.

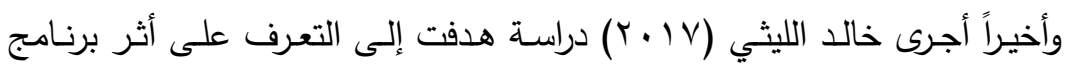
تعليمي مقترح قائم على أنماط التعلم لتتمية وظائف جانبي الدماغ الكلي، وذلك لدى عين الدئة

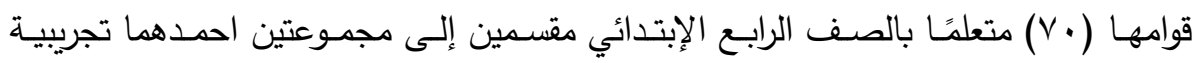
والأخرى ضـابطة قوام كل منها (0ب) تلميذًا، وبتطبيق مقياس جانبي الـماغ، واختبار

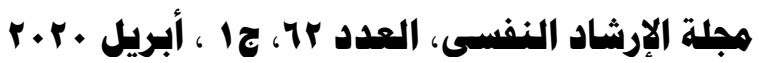


جانبي الدماغ في الرياضيات، وكذا البرنامج التعليمي المقترح؛ أسفرت النتائج عن تحسنًا دالاً إحصائيًا فى وظائف الدماغ الكلي لدى أفراد المجموعة التجريبية بعد تطبيق البرنامج.

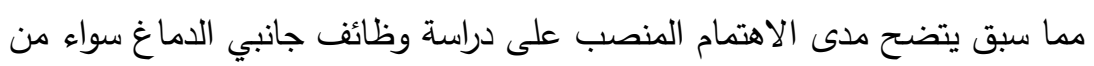

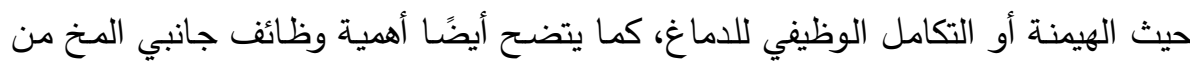
حيث ارتباطاتها بالعديد من المتغيرات النفسية المسهمة في تحقيق التوافق والصحة النفسية. التوصيات والمقترحات:

لعل من الملائم أن تختتم هذه الورقة البحثية بعدد من التوصيات والمقترحات التي تؤدى - ذأدات

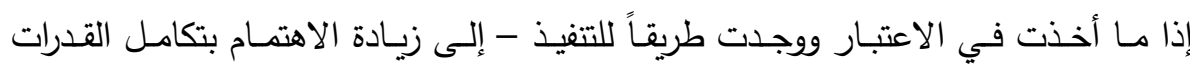
الدماغية فى مصر والعالم العربى، والتي ينعكس آثارها على النواحي الأكاديمية والنفسية والاجتماعية لاى الأفراد العاديين بشكل عام، ولذوي صعوبات التعلم والموهوبين والمتفوقين

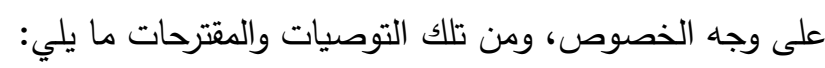

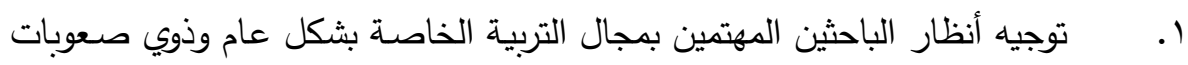
التعلم والموهوبين والمتقوقين بشكل خاص بإجراء مزيد من الدراسات والبحوث التى من شأنها تكامل القدرات الدماغية (وظائف جانبي الدماغ).

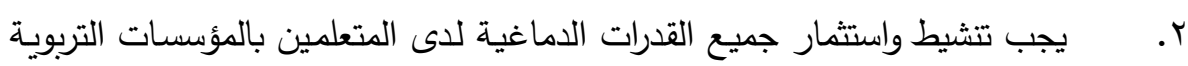

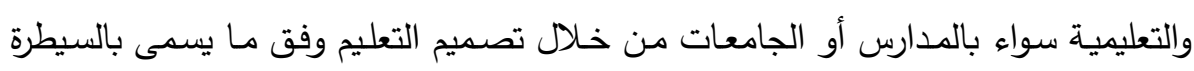

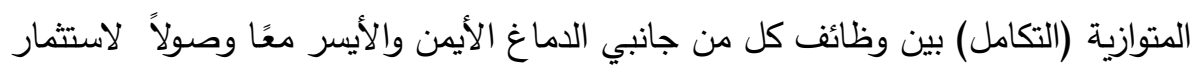
كامل طاقات الدماغ الانفعالية والمعرفية والسيكوحركية.

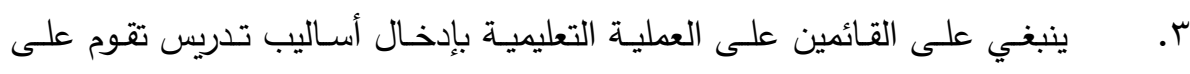
التدريس للنمط المتكامل وذلك من خلال تتاول عدة موضوعات في آن واحد بشكل متزامن (أسلوب تدريسي لنصف المخ الأيمن)، وتتاول المعلومات في توالى بشكل متتابع (أسلوب

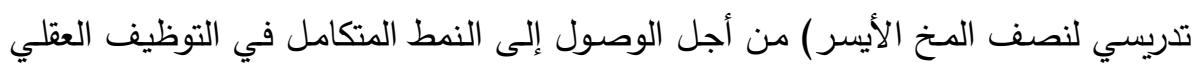
ومعالجة المعلومات.

وأخيراً، فبإن التوصـيات والمقترحسات السـابقة المقدمـة في هذه الورقـة البحثيـة ليست

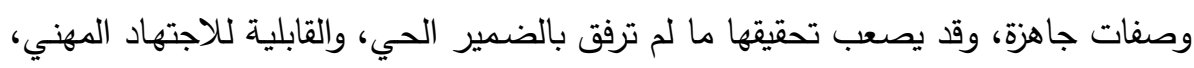

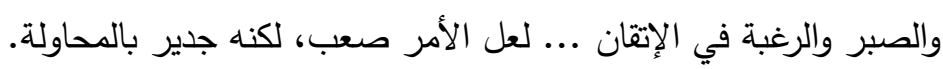

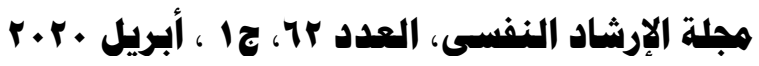




\section{$-$}

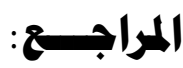

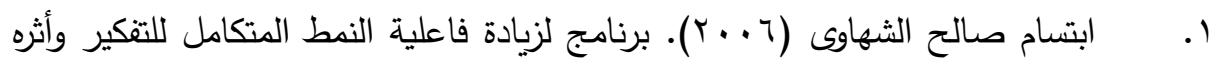

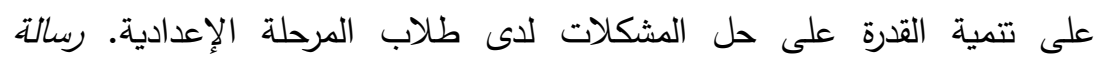
ماجستير، كلية التربية بالمنصورة، جامعة المنصورة.

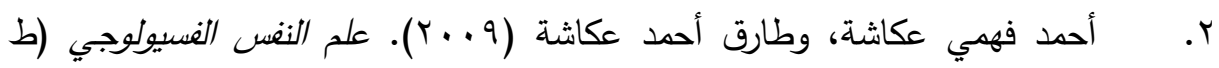
(1) (1) القاهرة: مكتبة الأنجلو المصرية.

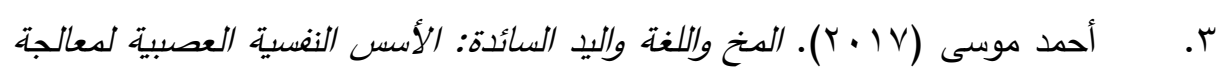

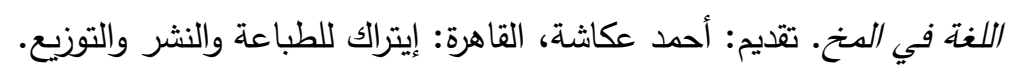

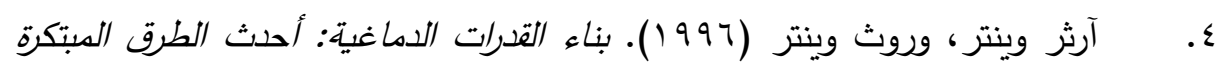

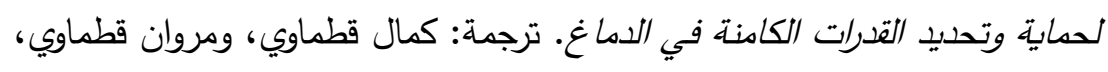

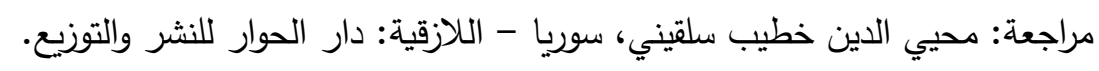

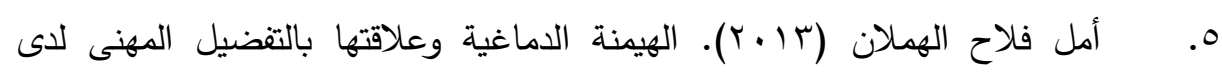

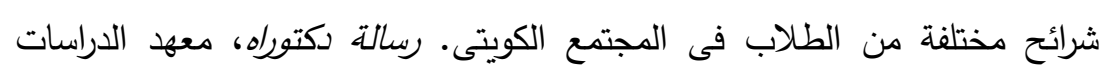

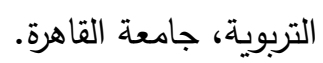

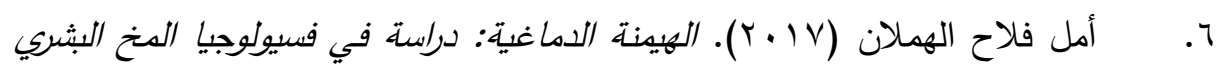

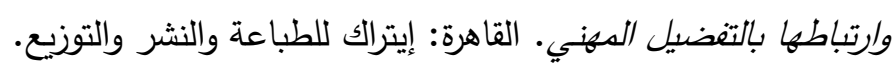

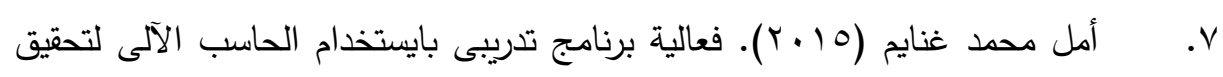

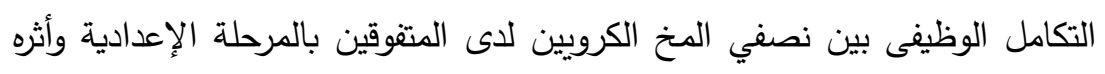

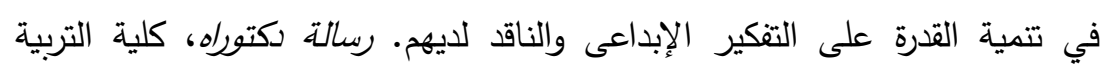
بالإنماعيلية، جامعة قناة السويس.

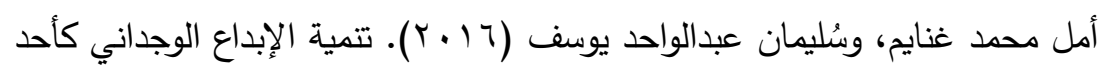
.$\wedge$

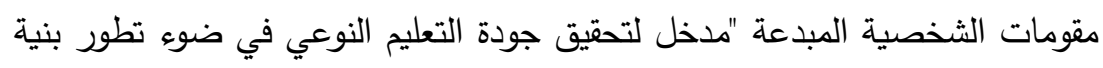

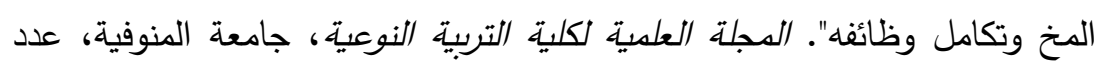

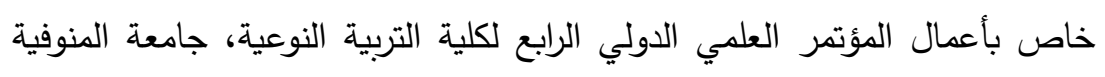

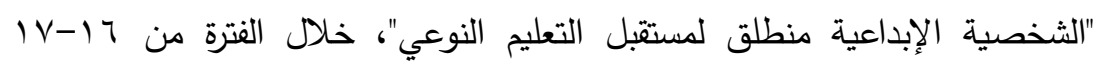

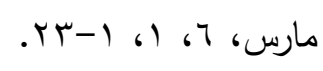

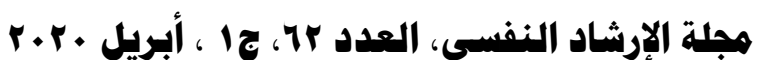




\section{بناء وتكاهل القدرات الدهاغية لدى العاديين وذوى صعوبات التعلم ع}

9 9. أمل محمد غنايم، ومحمد محمد شوكت، ونجلاء عبدالله الكلية (7 ( ب). فعالية

برنامج تدريبى بايستخدام الكمبيوتر في تحقيق التكامل الوظيفى بين نصفي المخ ونج

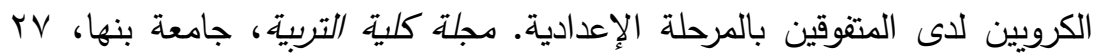

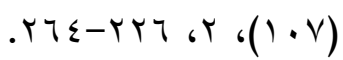

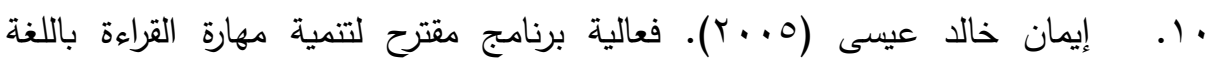

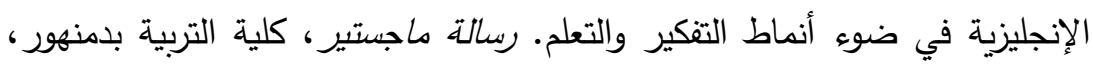

جامعة الإسكندرية.

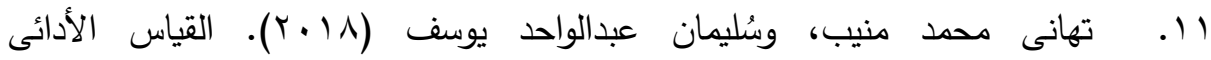

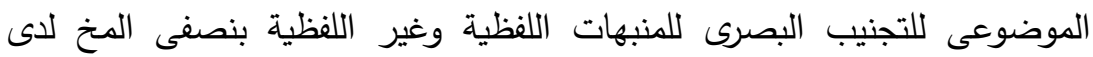
أطفال الروضة المعرضون لخطر صعوبات التعلم غير اللفظية وفق نظرية رورك

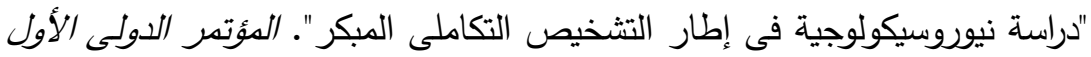
لكلية علوم الإعاقة والتأهيل بجامعة الزقازيق (الاتجاهات المعاصرة في تعليم وتأهيل

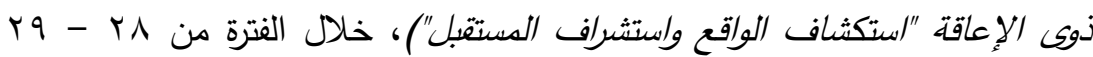
يوليو، والمنعقد بكلية علوم الإعاقة والتأهيل بجامعة الزقازيق، . . IV - IV. r I. دانيال هالاهان، وجيمس كوفمان، وجون لويد، ومارجريت ويس، وإليزابيث مارتنيز

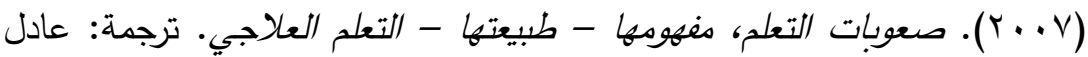
عبد الله محمد، عمّان: دار الفكر للنشر والتوزيع.

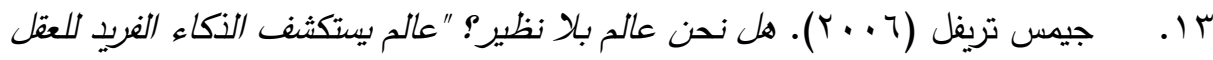

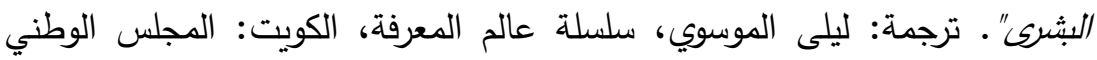

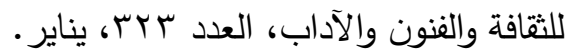

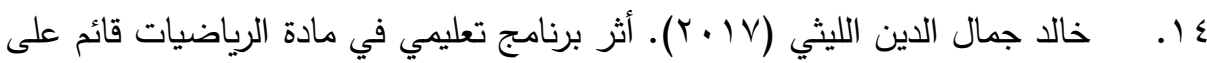
انماط التعلم لتتمية وظائف جانبي والدماغ الكلي والحس العددي لدى تلاميذ المرحلة

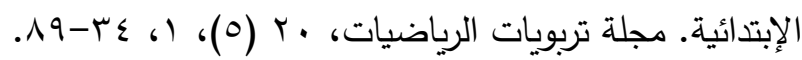
10. ديفيد سوسا (9 . . r). العقل البشرى وظاهة التعلم. ترجمة: خالد العامري، القاهرة: دار الفاروق للاستثمارات الثقافية. 
(ب

17. رحمه بنت ناصر بني عرابه (ع .. ب). أنماط السيطرة المخية لدى التلاميذ ذوى

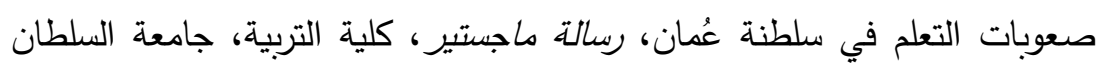
قابوس.

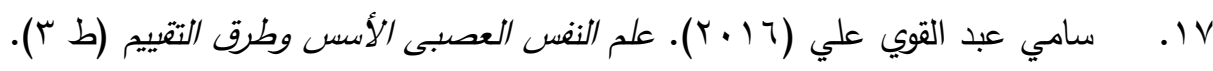
القاهرة: مكتبة الأنجلو المصرية.

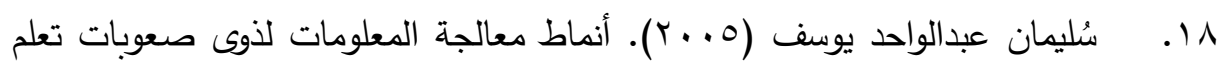
مادة العلوم في إطار نموذج التخصص الوظيفي للنصفين الكرويين بالمخ لتلاميذ المرحلة الإعدادية. رسالة ماجستير ، كلية التربية بالإسماعيلية، جامعة قناة السويس.

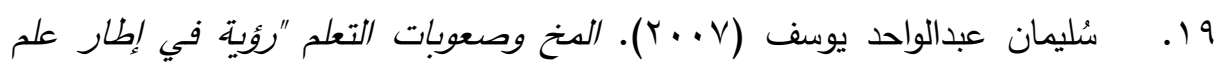
النفس العصبي الدعرفي" . القاهرة: مكتبة الأنجلو المصرية.

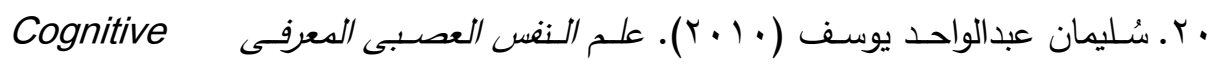
Neuoropsychology إيتراك للطباعة والنشر والتوزيع. سُليمان عبد الواحد يوسف (1) (1 أ). أثر تتمية وظائف النمط المتكامل للنصفين $\cdot r$ الكرويين بالمخ لذوى صعوبات التعلم على التحصيل في مادة العلوم في إطار نموذج المعالجة المعرفية المتتابعة والمتزامنة لتكامل المعلومات بالميخ لتلاميذ المرحلة الإعدادية. رسالة دكتوراه، كلية التربية بالسويس، جامعة قناة السويس.

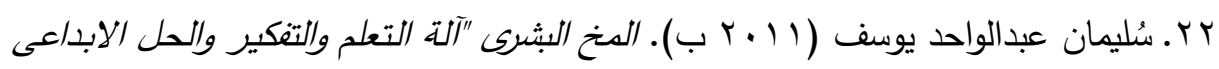
للمشكلات" ـ القاهرة: مؤسسة طيبة للنشر والتوزيع.

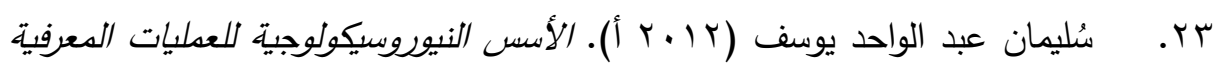

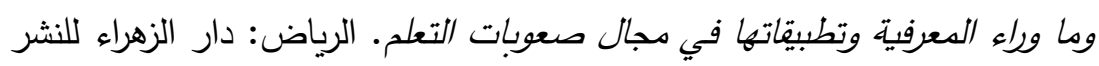
والتوزيع.

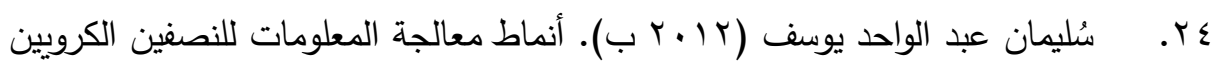

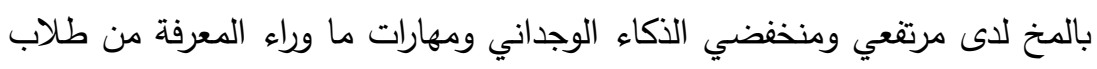

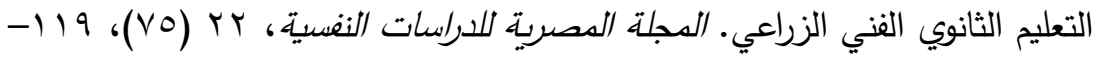
.171

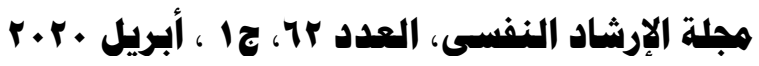




\section{بناء وتكاهل القدرات الدهاغية لدى العاديين وذوى صعوبات التعلم ع}

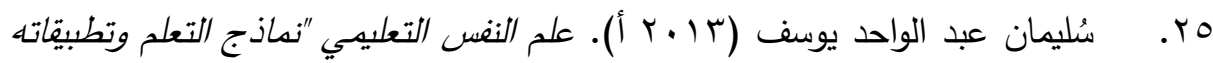

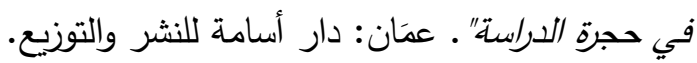

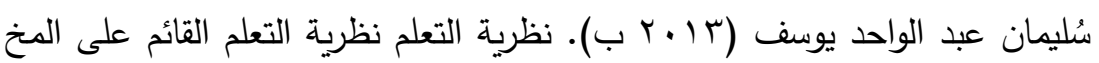

الإنسانى وتطبيقاتها فى مجال صعوبات التعلم "رؤية نيوروسيكولوجية وإنعكاسات

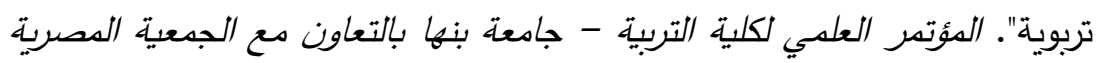

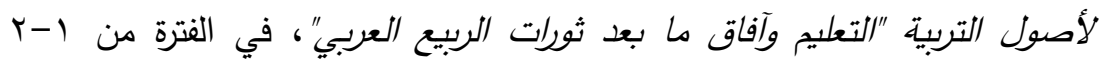

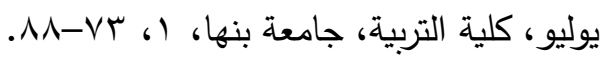

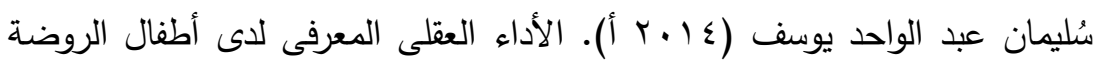

ذوى صعوبات التعلم النمائية فى ضوء إصابة النصفين الكرويين للمخ وأنماط

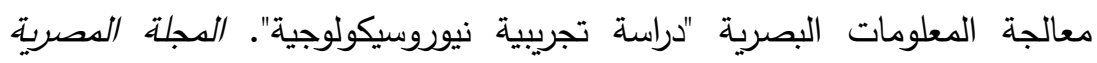

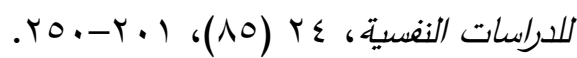

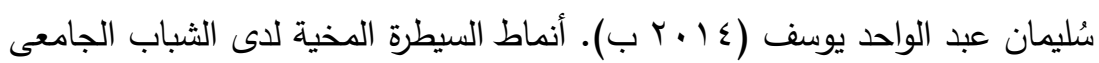
. $\mathrm{\wedge}$ الموهوبين ذوى صعوبات التعلم والعاديين "دراسة نيوروسيكولوجية باستخدام الكمبيوتر

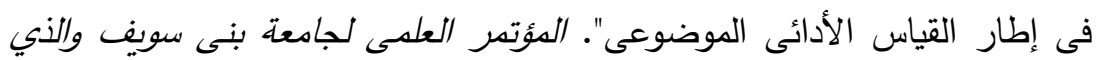
تنظمه ببناسبة الاحتفال باليوم العالمى للإعاقة بعنوان (شبابنا طاقة ل .. لا إعاقة)

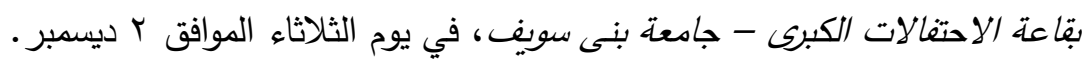

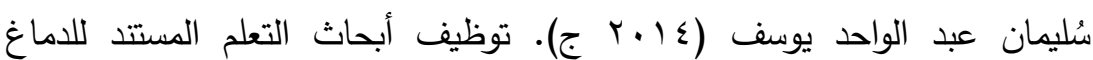
(BBL)

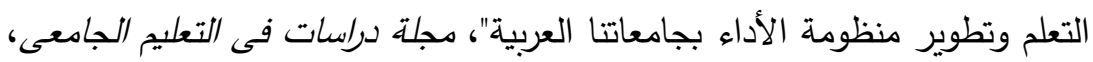

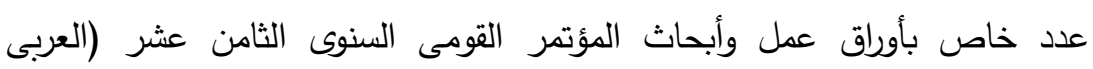
العاشر) لمركز تطوير التعليم الجامعى بالتعاون مع جامعة الدول العربية" تطوير

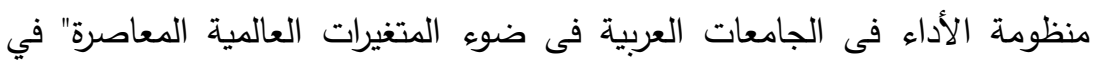

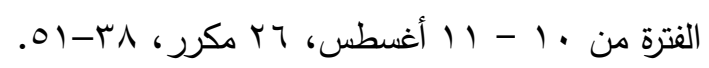

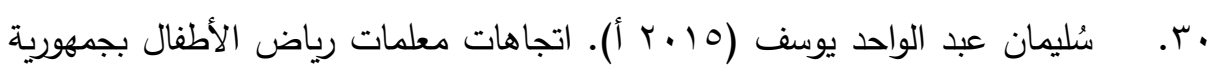
مصر العربية نحو الأطفال المعرضين لخطر صعوبات التعلم وعلاقتها بالسيادة

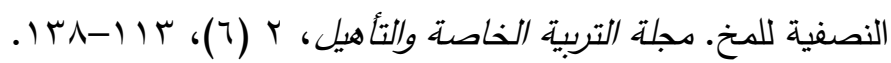

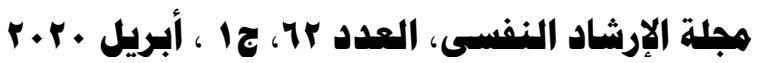




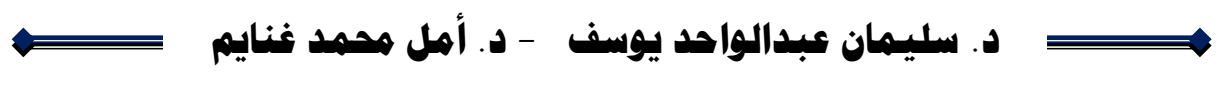

ابـ سُليمان عبد الواحد يوسف (10 ب ب). مخخ الإنسان آلة تجهيز ومعالجة الدعلومات

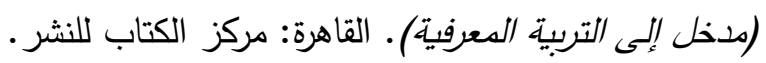

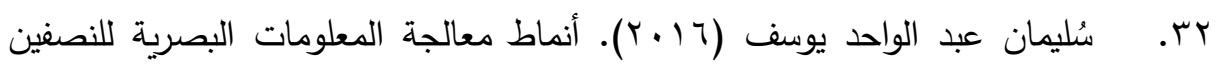

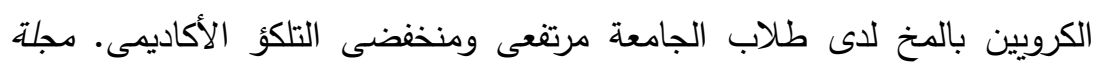

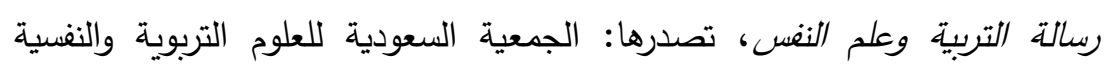

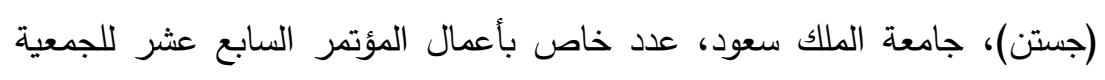

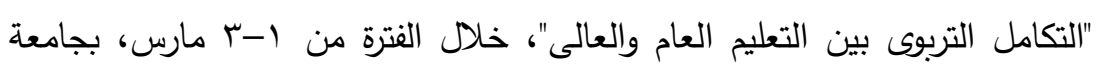

الملك سعود،

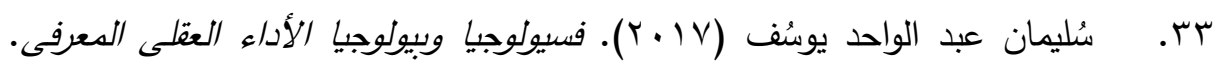

عمّان: دار المناهج للنشر والتوزيع.

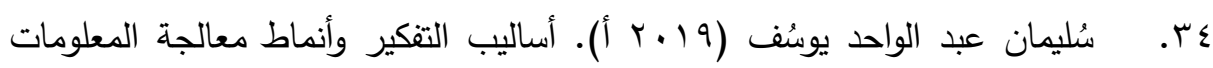

المرتبطة بنصفي المُخ لاى مرتفعي ومنخفضي المناعة النفسية من المُسنين مرضى لئى

باركينسون "دراسة نيوروسيكولوجية فى إطار التفاعل بين المُخ وجهاز المناعة".

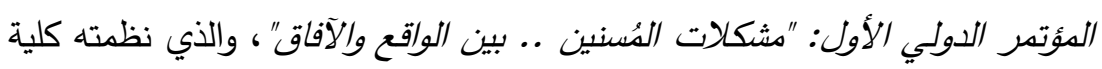

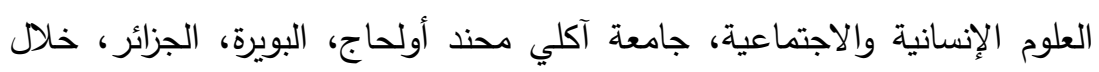

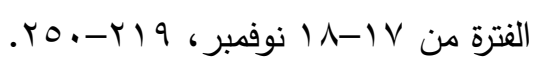

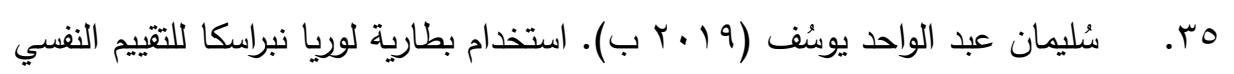

العصبي في التشخيص الفارق بين الأطفال ذوي صعوبات تعلم النصف الأيمن للمخ

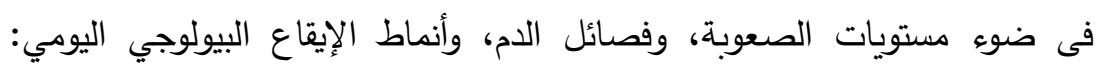

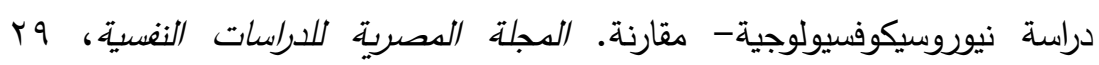

$$
\text { . } r \wedge \varepsilon-r \leqslant) ،(1 \cdot \varepsilon)
$$

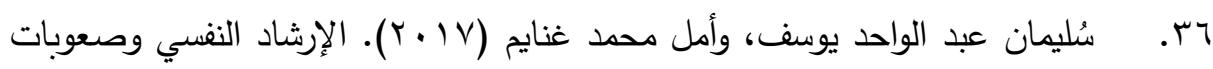
التعلم "دور المرشد النفسي المدرسي في الكثف عن ذوي صعوبات التعلم من

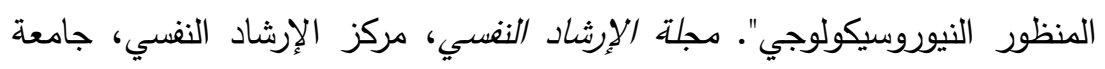

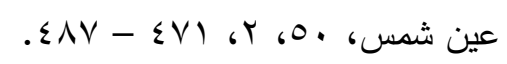

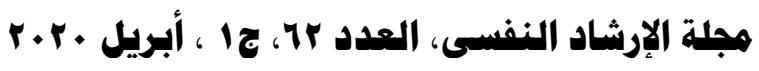




\section{بناء وتكاهل القدرات الدهاغية لدى العاديين وذوى صعوبات التعلم ع}

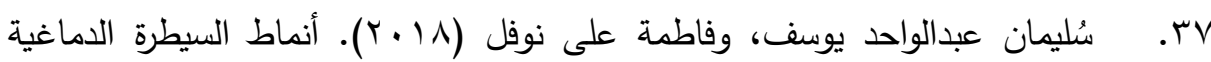

لاى فئات متباينة من الأطفال ذوى صعوبات التعلم النوعية. المؤتمر الدولى الأول لكلية علوم الإعاقة والتتأهيل بجامعة الزقازيق (الاتجاهات الدعاصرة في تعليم وتأهيل

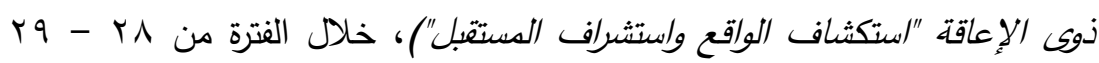

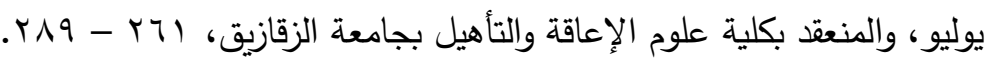

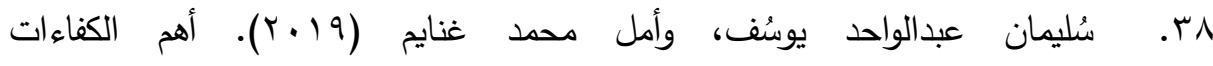

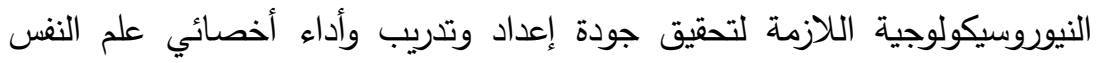
العصبي فى مجالات الموهبة والتثوق وصعوبات التعلم. المجلة العربية لبحوث

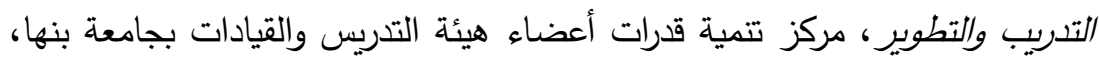

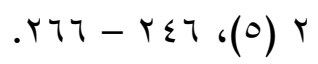

9 ب. شاكر عبد الحميد سُليمان (991 (19). الفروق بين الجنسين في أساليب التعلم والتفكير

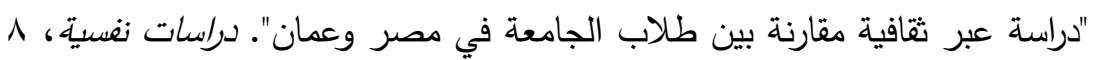

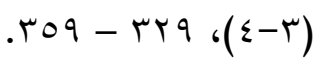

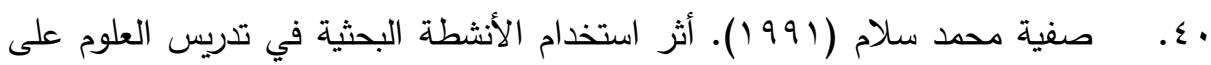

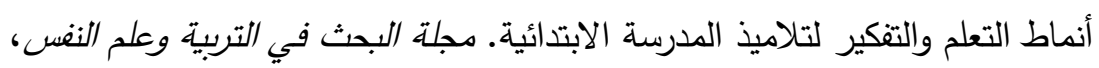

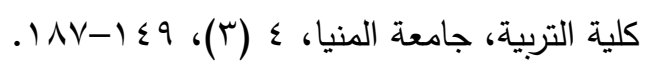

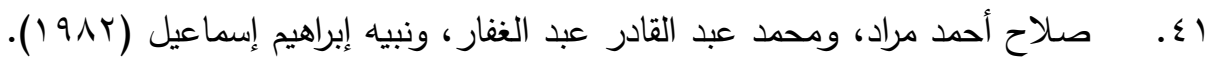

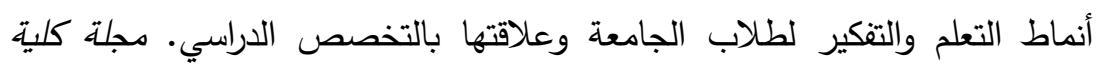

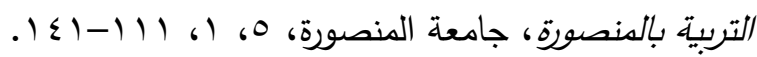

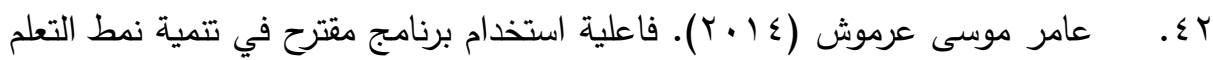
المتكامل للدماغ واكتساب المفاهيم العلمية لدى طلاب الصف السابع الأساسي. رسالة ماجستير ، كلية الدراسات العليا، الجامعة الأردنية.

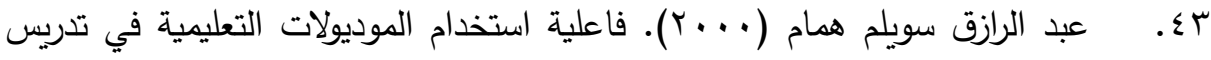
العلوم على أنماط التعلم والتفكير وإتقان المفاهيم العلمية لدى تلاميذ الصف الخامس لإنه الابتدائي. مجلة البحث في التربية وعلم النفس، كلية التربية، جامعة المنيا، ع ا (Y)، 


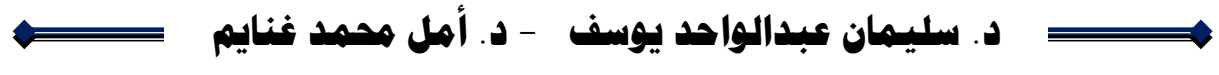

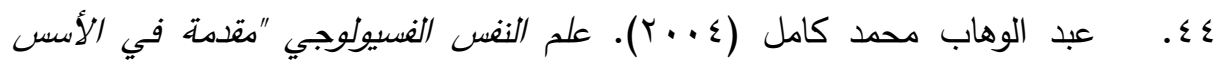

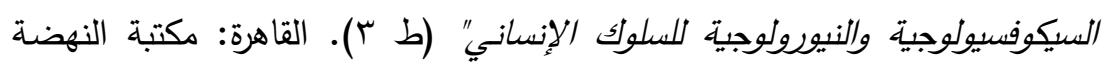

$$
\begin{aligned}
& \text { المصرية. } \\
& \text { 0ـ. عزو إسماعيل عفانة، ويوسف إبراهيم الجيش (9 . . ب). التدريس والتعلم بالدماغ ني } \\
& \text { الجانبين. عمَان: دار الثقافة للنشر والتوزيع. } \\
& \text { على أحمد سيد، ومصطفى عبدالمحسن الحديبى، ومحمد أحمد يوسف (10 بـ ب). } \\
& \text { مبادىء علم النضس الحيوى. عمّان: دار المسيرة للنشر والتوزيع والطباعة. }
\end{aligned}
$$

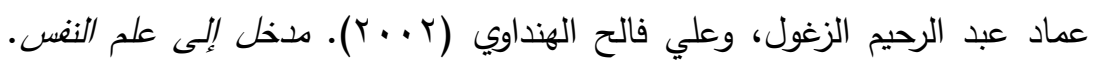

$$
\begin{aligned}
& \text { العين: دار الكتاب الجامعي، الإمارات العببية الدتحدة. } \\
& \text { والتوزيع والطباعة. }
\end{aligned}
$$

محمد رشدي محمد (ب991 (1). بناء برنامج لتتمية النمط المتكامل من أنماط التعلم

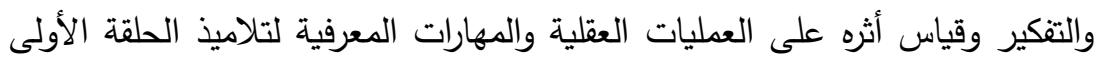
من التعليم الأساسي. رسالة دكتوراه، كلية التربية، جامعة المنيا.

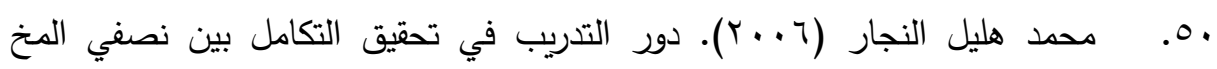
الكرويين لعينة من طلاب وطالبات الصف الثاني الإعدادي. رسالة دكتوراه، معهد الدراسات والبحوث التربوية، جامعة القاهرة.

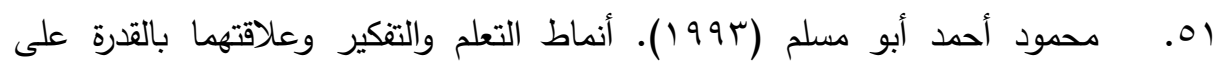
التصور البصري و المكاني والاستقلالي الادراكي لاي الفائقين والعاديين من طلاب

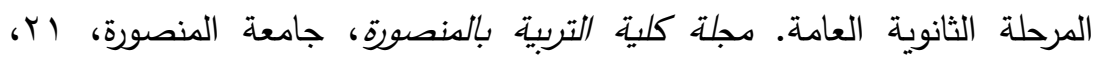
$. r V \leqslant-r T)$

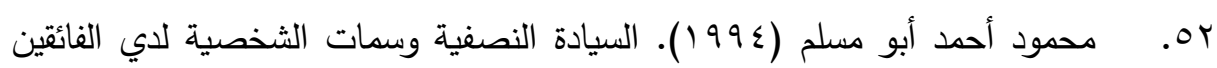

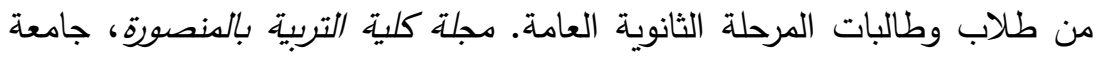

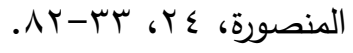

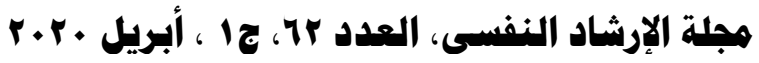




\section{بناء وتكاهل القدرات الدهاغية لدى العاديين وذوى صعوبات التعلم ع}

ror. محمود فتحي عكاشة (1991). أنماط معالجة الدعلومات وعلاقتها بالتفضيلات

المهنية للأفراد. القاهرة: مكتبة النهضة المصرية.

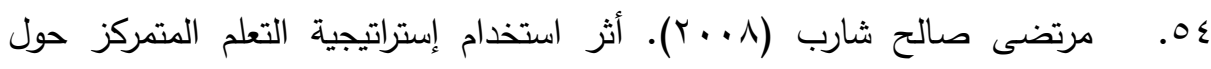

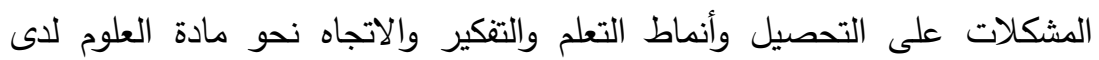

تلاميذ المرحلة الإعدادية، رسالة ماجستير، كلية التربية بأسيوط، جامعة أسيوط.

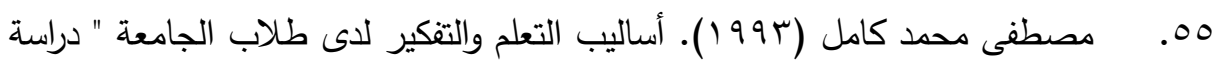

مقارنة عبر ثقافية في ست دول عربية". مجلة كلية التربية بالمنصورة، جامعة ولئ

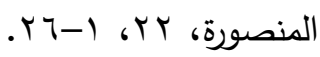

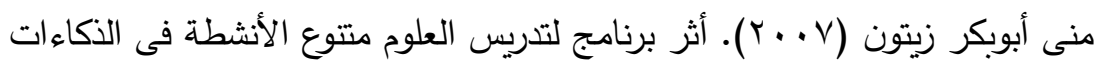
.07

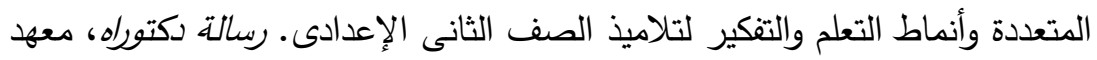
الدراسات والبحوث التربوية، جامعة القاهرة.

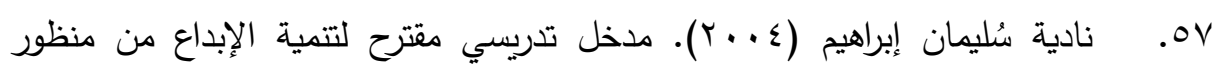

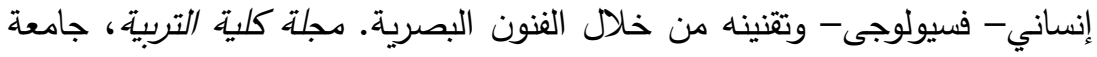

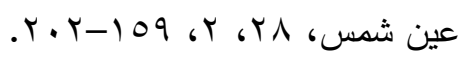

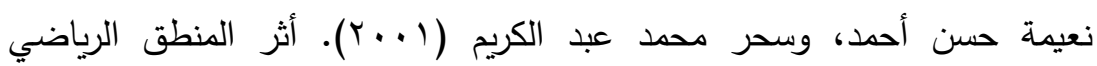

والتدريس بالمدخل البصري المكاني في أنماط التعلم والتفكير وتتمية القدرة المكانية وتحصل تلاميذ الصف الثاني الإعدادي في مادة العلوم. المؤتر العلمي الخامس ليس

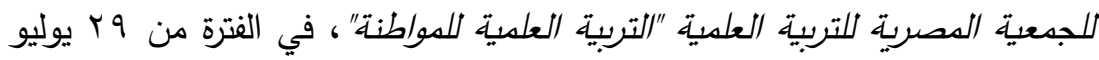

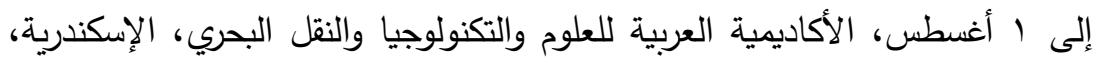
$. O V Y-O Y O G$

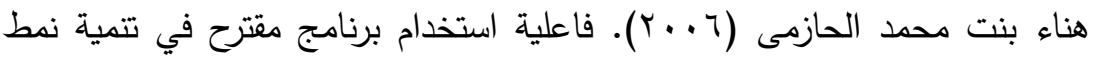
.09 تعلم النصف كروي الأيمن للدماغ لدى طالبات العلوم بالمرحلة المتوسطة بالمدينة المنورة. رسالة ماجستير، كلية التربية والعلوم الإنسانية، جامعة طيبة، المملكة العربية 


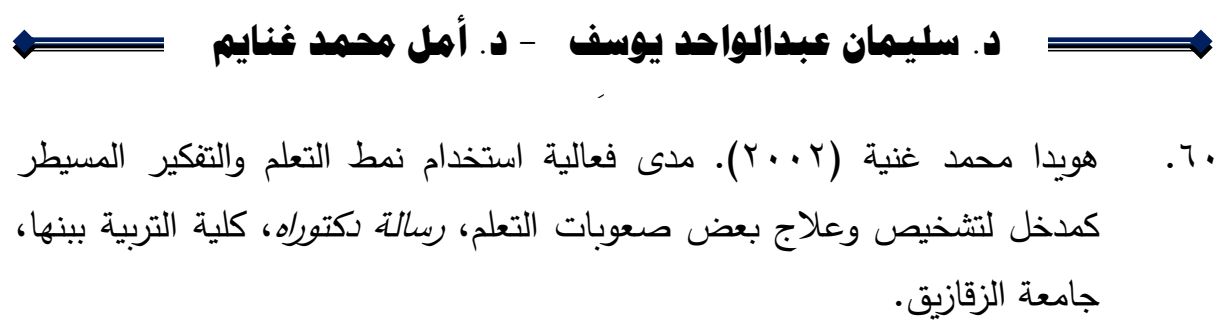

61. Caine, R. \& Caine, G. (1997). Making connection: Teaching and Brain, Alexandraia, va: ASCD.

62. Hellige, J. B. (2006). Evolution of brain lateralization in humans. Cognition, Brain, Behavior, 10 (2), 211-234.

63. Monaghan, P. \& Shillcock, R. (2004). Hemispheric asymmetries in cognitive modeling: connectionist modeling of unilateral visual neglect. Psychological Review, 111 (2), 283308.

64. Reynolds, C. R. \& Torrance, E. P. (1978). Perceived changes in style of learning and thinking (hemispheric) through direct and indirect training. Journal of Creative Behavior, 12 (4), 1214.

65. Torrance, E. P. (1975). Sociodrama as a creative problemsolving approach to studying the future. The Journal of Creative Behavior, 9 (3), 182-195.

66. Torrance, E. P. (1981). Sounds and lmages lmagery as a potential lndicator of style learning and thinking. The Journal of Creative Behavior, 15 (4), 279.

67. Torrance, E. P. \& Mourad, S. A. (1979). Role of hemisphericity in performance an selected measures of creativity. Gifted Child Quarterly, 23, 44-54.

68. Torrance, E. P. \& Okabayashi, H. (1984). Role of style learning and thinking and self directed learning readiness in the achievement of gifted students. Journal of Learning Disabilities, 17 (2), 104 - 107.

69. Wisniewski, A. B. \& Prendeville, M. T. \& Dobs, A. S. (2005). Handedness, functional cerebral hemispheric lateralization, and cognition in male-to-female transsexuals receiving crosssex hormone treatment. Archives of Sexual Behavior, 34 (2), 167-172.

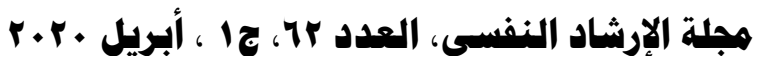

(430) 


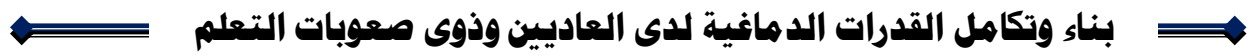

Building and integrating the brain capabilities of the ordinary, people with learning disabilities, talented and excelling in the framework of developing the mental structure in order to empower the Egyptian and Arab people

"Psychophysiological and neuropsychological vision of information processing"

\author{
Prepared by \\ Dr. Soliman abd El Wahed Yousef \\ $\mathrm{Ph} . D$. in Educational psychology, Learning Disabilities, \\ Faculty of Education - Suez Canal University \\ Dr. Amal Mohammed Ghanayem \\ Lecturer of Special Education, \\ Faculty of Education in Ismailia - Suez Canal University
}

\begin{abstract}
$\underline{\text { Abstract }}$
The present research paper deals with building and integrating the brain capabilities of different groups of society who are: ordinary and people with learning disabilities and talented, through a presentation of the human brain and what it is and its main components, as well as a presentation of brain dominance, functional integration of both sides of the human brain, and finally a presentation of Arab studies and research That dealt with the functional integration of both sides of the brain in the ordinary, people with learning disabilities, the gifted, and talented in all age groups Finally, the research paper concluded with recommendations and proposals that can lead - if you take into account and find a way to implement - to build and integrate the brain capabilities of ordinary and people with learning disabilities, talented and excelling in the framework of developing the mental structure in order to enable the Egyptian and Arab people.

Keywords: The human brain - Brain abilities - Learning disabilities Talent - Excellence - psychophysiology - Neuropsychological Information processing.
\end{abstract}

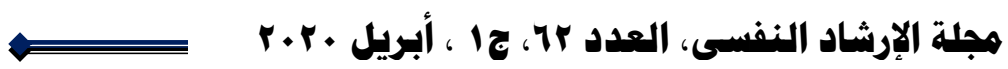

